\title{
Dergiabant
}

Cilt/Volume: 9, Sayı/Issue: 1

(Mayıs/May 2021)

\section{İsmâil Hakkı Bursevî'nin Şerhu Nuhbeti'l-fiker Adlı Eserinde Ali el-Kârî̀ye Karşı Takındığı Olumsuz Tavrın Muhtemel Sebepleri Üzerine Bir Değerlendirme}

\section{An Assesment of Ismā̄īl Haqqī Bursavī in His Work Titled Sharḥ Nukhbat al-fikar about Possible Causes of His Negative Attitude for 'Alī al-Qārī}

\section{Necmi Sarı}

Dr. Öğr. Üyesi, Bolu Abant İzzet Baysal Üniversitesi, İlahiyat Fakültesi, Hadis Anabilim Dalı

Asst. Prof. Dr., Bolu Abant Izzet Baysal University,

Faculty of Theology, Department of Hadith

Bolu/Turkey

necmisari@ibu.edu.tr

orcid.org/0000-0003-0910-7691

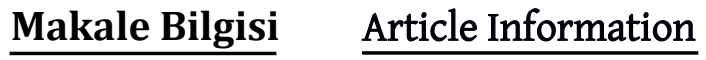

Makale Türü: Araştırma Makalesi

Geliş Tarihi: 21 Ocak 2021

Kabul Tarihi: 1 Mart 2021

Yayın Tarihi: 30 Mayıs 2021

Yayın Sezonu: Bahar
Article Type: Research Article

Date Received: 21 January 2021

Date Accepted: 1 March 2021

Date Published: 30 May 2021

Publication Season: Spring

https://doi.org/10.33931/abuifd.866106

İntihal/Plagiarism

Bu makale özel bir yazılımla taranmış ve intihal tespit edilmemiștir.

This article has been scanned by a special software and no plagiarism detected.

\section{Atıf/Cite as}

Sarı, Necmi. “İsmâil Hakkı Bursevî’nin Şerhu Nuhbeti'l-fiker Adlı Eserinde Ali el-Kârî’ye Karşı Takındığı Olumsuz Tavrın Muhtemel Sebepleri Üzerine Bir Değerlendirme”. Dergiabant 9/1

(Mayis 2021), 1-26. https://doi.org/10.33931/abuifd.866106

Copyright @ Published by Bolu Abant Izzet Baysal University Faculty of Theology, Bolu, 14030 Turkey. All rights reserved. https://dergipark.org.tr/tr/pub/dergiabant 


\title{
İsmâil Hakkı Bursevî'nin Şerhu Nuhbeti'l-fiker Adlı Eserinde Ali el-Kârî̀ye Karşı Takındığı Olumsuz Tavrın Muhtemel Sebepleri Üzerine Bir Değerlendirme
}

Öz

Şerhu Nuhbeti'l-fiker adlı eserinde, Ali el-Kârînnin Şerhu Şerhi Nuhbeti'l-fiker adlı eserinden çok fazla istifade ettiği anlaşılan, hatta intihal derecesine varacak seviyede bu eserden alıntılar yaptığı müșahade edilen Bursevî'nin bu eserinde göze çarpan en büyük problem Bursevî'nin Ali el-Kârî̀ye karşı takındığı olumsuz tavırdır. Bursevî şerhinin hiçbir yerinde Ali el-Kârî ve eserinin ismini zikretmemiş, hatta ondan söz ederken imalı ve alaycı bir üslup kullanmıș, nadiren de olsa hakaret içeren ifadelerle ona işaret etmiştir. Bursevî̀nin, Ali el-Kârî̀ye karşsı takındığı bu olumsuz tavrı, o dönemdeki nakil geleneğiyle veya Ali el-Kârînnin şerhinin ismini zikretmeye ihtiyaç bırakmayan şöhretiyle açıklamak mümkün olmadığı gibi Ali el-Kârînnin, Muhyiddîn İbnü'l-Arabî karşııtı cephe olan Kadızâdeliler tarafında yer almasına bağlamak da mümkün gözükmemektedir. Zira Bursevî'nin Şerhu Nuhbeti'l-fiker dışındaki bazı eserlerinde Ali el-Kârî ve eserinden ismen söz ettiğini tesbit etmiş bulunmaktayız. Buna ilâveten Bursevî'nin muhtelif eserlerinde, Ali el-Kârî'nin Şerhu Şerhi Nuhbeti'lfiker'i dışındaki diğer eserlerinden bahsederken bazen müellif ve eser ismi birlikte, bazen sadece müellif ismiyle, bazen de müellif ismi olmadan eser isimleriyle söz etmesi bu kanaatimizi destekler mâhiyettedir. Bu kanaatimizi destekleyen diğer bir husus da Bursevînnin mezkur eserlerini te'lif ettiği tarihler dikkate alındığında, zaman içinde Ali el-Kârî hakkındaki düşüncelerinde olumludan olumsuz yöne veya olumsuzdan olumlu yöne doğru bir kayma olduğu ihtimalinin ortadan kalkmış olmasıdır. Bütün bu zikredilen hususlardan sonra Bursevî̀nin Ali el-Kârî̀ye karş̧ takındığı bu olumsuz tavra neden olabileceğini düşündüğümüz tek bir sebep kalmaktadır ki o da Bursevî̀nin kendi şerhinin, Ali el-Kârî̀nin şerhinin gölgesinde kalmasını istemediği için böyle bir yöntem ve üslup benimsemiş olabileceği ihtimalidir. Bursevî bu eserin bilinmesini özellikle istememiş olabilir.

Anahtar Kelimeler: Hadis, Şerh, Ali el-Kârî, Bursevî, Şerhu Nuhbeti'l-fiker.

\section{An Assesment of Ismāîil Ḥaqqī Bursavī in His Work Titled Sharh Nukhbat al-fikar about Possible Causes of His Negative Attitude for 'Alī al-Qārī}

\begin{abstract}
The biggest problem in Bursavi's book Sharh Nukhbat al-fikar -which is understood that he benefited a lot from 'Alī al-Qārī's Sharh Sharh Nukhbat al-fikar and even made citation from this work at the level of plagiarism- is Bursavì's negative attitude against 'Alī al-Qārī. Bursavī did not mention the name of 'Alī al-Qārī and his work anywhere in the commentary, and even used an implied and sarcastic style when talking about him, and rarely pointed to him with insulting expressions. Bursavi's negative attitude towards 'Alī al-Qārì could not be explained by the tradition of the transplant at that time or by his reputation that did not require mentioning the name of 'Alī al-Qārī's commentary, as well as the views 'Alī al-Qārī put forward in most of the related discussion topics. It does not seem possible to attribute it to the side of the Kādīzādeli movement, which is the anti-Muhyī'l-Dīn Ibn al-'Arabī front. Because we have determined that Bursavī mentions 'Alī al-Qārī and his work by name in some of his works, except Sharh Nukhbat al-fikar. After all these mentioned issues, there remains only one reason that we think that Bursavī's negative attitude towards 'Alī al-Qārī can cause this negative attitude, which is such a method because he does not want Bursavī's own commentary to remain in the shadow of 'Alī al-Qārī's commentary and It is possible that he may have adopted style. Bursavì may not have specifically wanted this work to be known.
\end{abstract}

Keywords: Hadīth, Comment, 'Alī al-Qārī, Bursavī, Sharḥ Nukhbat al-fikar. 


\section{Giriş}

İbn Hacer'in (öl. 852/1449) Nüzhetü'n-nazar fî tevdîhi Nuhbeti'l-fiker'i üzerine yazılmış birçok şerh vardır. Bu şerhlerden biri de 1063/1653-1137/1725 yılları arasında yaşamış olan Osmanlı âlimi İsmâil Hakkı Bursevî'nin Nuhbetü'l-fiker şerhidir (SSerhu Nuhbeti'l-fiker). ${ }^{1}$ Bursevî bu şerhinde, ortaya koyduğu tasavvufî ve bâtınî yaklaşımlarının bir sonucu olarak zarûrî haller dışında ma'nen rivâyetin câiz olmadığına dair görüşü, makbûl (sahih ve hasen), zayıf ve mevzû hadislere bakışı, mevkûf hadisleri ele alışı, mukayyed sünnet anlayışı, hadis tesbitinde kullandığı bilgi kaynakları olan ahz anillah, ilhâm, keşif, insilâh, rüya ve yakaza, hadis tesbit ölçüleri olarak kullandığı âlimlerin ve büyük velîlerin eserlerinde bulunan hadisler, mânâsı doğru olan hadisler, kelâm-ı kibâr olan sözler ve mânâ âlemindeki hâdiseler gibi usûle yönelik konularda hadis âlimlerinden farklı bir metot izlemiştir. ${ }^{2}$

Başından sonuna kadar şerhinde, Ali el-Kârî'nin (öl. 1014/1605) Şerhu Şerhi Nuhbeti'l-fiker ${ }^{3}$ adlı eserinden çok fazla istifade ettiği anlaşılan, hatta intihal derecesine varacak seviyede bu eserden alıntılar yaptığı müşahade edilen Bursevî'nin bu eserinde göze çarpan en büyük problem Bursevî’nin Ali el-Kârî̀ye (öl. 1014/1605) karşı takındığı olumsuz tavırdır. Bursevî șerhinin hiçbir yerinde Ali el-Kârî ve eserinin ismini zikretmemiş, hatta ondan söz ederken imalı ve alaycı bir üslup kullanmış, nadiren de olsa hakaret içeren ifadelerle ona işaret etmiştir.

\section{Bursevî'nin Yaşadığı Dönemde Medrese-Tekke Tartışmaları}

Bursevî’nin yaşadığı dönem (1063/1653-1137/1725), öncesinde olduğu gibi Osmanlı'da vahdet-i vücûd müdâfii Muhyiddîn İbnü'l-Arabîn (öl. 638/1240) ve eseri Fusûsu'l-hikem merkezli tartışmaların, medrese-tekke veya başka bir ifadeyle Kadızâdeliler-Sivâsîler kutuplaşmasının ekseninde yoğun bir şekilde yaşandığı dönemdir. ${ }^{5}$ Muhyiddîn İbnü'l-Arabî'yi sahiplenen başını Abdülmecîd Sivâsî

Nuhbetü'l-Fiker șerhi ifadesiyle Nüzhetü'n-Nazar șerhi kastedilmektedir. bk. Necmi Sarı, İsmail Hakkı Bursevînin SSerhu Nuhbeti'l-Fiker Adl Eserinin Tahkik ve Tahlili (Sakarya: Sakarya Üniversitesi Sosyal Bilimler Enstitüsü, Doktora Tezi, 2017), 114-118. Bu konular hakkında ayrıntılı bilgi için bk. Sarı, Ísmail Hakkı Bursevî́nin Şerhu Nuhbeti'l-Fiker Adlı Eserinin Tahkik ve Tahlili, 155-308.

3 Bursevî, Ali el-Kârî̀nin bu eserini Şerhu'n-Nuhbe olarak isimlendirmektedir. bk. Bursevî, İsmâîl Hakkî, Furûku Hakkî [Mehmet Faruk Çifçi, İsmâil Hakkı Bursevî́nin Furûk-ı Hakkı Adlı Eseri (İnceleme ve Tahkik) (İstanbul: Marmara Üniversitesi Sosyal Bilimler Enstitüsü, Doktora Tezi, 2013)], 33, 66, 244; a.mlf., Rûhu'l-beyân fî tefsîri'l-Kur'ân, nșr. Abdüllatîf Hasen Abdurrahmân (Beyrut: Dârü'l-Kütübi'l-İlmiyye, 1430/2009), 8/545; 10/44. krş. Sarı, İsmail Hakkı Bursevî’nin Şerhu Nuhbeti'l-Fiker Adlı Eserinin Tahkik ve Tahlili, 118.

4 Muhyiddîn İbnü'l-Arabî'nin bu konu hakkındaki görüşleri için bk. Değaş b. Şebîb el-Acmî, İbn Arabî akîdetuhu ve mevkıfu ulemâi'l-müslimîn minhu mine'l-karni's-sâdis ile'l-karni's-sâlis aşer (Kuveyt: Mektebetü Ehli'l-Eser, 1432/2011), 41-52.

5 İlgili dönem ve tartışmaları hakkında geniş bilgi için bk. Kâtib Çelebi, Hacı Halîfe Mustafa b. Abdullah, Mîzânu'l-hak fî ihtiyâri'l-ehak İslâmda Tenkid ve Tartışma Usûlü (haz. Mustafa Kara, İstanbul: Marifet Yayınları, 1981), 40-161, 162-164; a.mlf., Fezleke-i Kâtib Çelebi (İstanbul: Cerîde-i Havâdis Matbaası, 1310), 2/183; Naîmâ, Mustafa, Târîh-i Naîmâ (Ravzatü'l-hüseyn fî hulâsati ahbâri'l-hâfikayn) (İstanbul: Matbaa-i Âmire, 1280), 6/219-220; İsmail Hakkı Uzunçarşıll, Osmanlı Tarihi (Ankara: Türk Tarih Kurumu, 1988), 3(1)/354-366; Mehmet Kalaycı, Osmanlı Sünniliği Tarihsel-Sosyolojik Bir Tahlil Denemesi (Ankara: Otorite Yayınları, 2015), 200201, 202-214, 245-293; a.mlf., "Birgivî Mirasının Toplumsal ve Metinsel Taşıyıcıları: Kadızâdeliler ve Etrafındaki Ulema", Sahn-ı Semân'dan Dârulfünûn'a Osmanlı'da İlim ve Fikir 
Efendi'nin ${ }^{6}$ (öl. 1049/1639) çektiği Sivâsîler, genellikle Halvetiyye ve Bayramiyye tarikatına mensup sûfî meşrebli kimselerdir.7 Kadızâdeliler ise Çivizâde Muhyiddîn Mehmed Efendi $^{8}$ (öl. 954/1547), İbrâhim el-Halebî Efendi ${ }^{9}$ (öl. 956/1549), Birgivî Mehmed Efendi10 (öl. 981/1573), Ali el-Kârî11 (öl. 1014/1605), Abdürraûf

Dünyası (Âlimler, Müesseseler ve Fikrî Eserler) - XVII. Yüzyıl Sempozyum Tebliğleri, ed. Hidayet Ardar - Ali Fikri Yavuz (İstanbul: Zeytinburnu Belediyesi, 2017), 438-439, 442-454; Semiramis Çavuşoğlu, "Kadızâdeliler", Türkiye Diyanet Vakfı İslâm Ansiklopedisi (İstanbul: TDV Yayınları, 2001), 24/100-102; Ali Namlı, İsmâil Hakkı Bursevî Hayatı, Eserleri, Târikat Anlayışı (İstanbul: İnsan Yayınları, 2001), 24-26; İbrahim Baz, Kadızadeliler Sivasiler Tartışması (Ankara: OTTO, 2019), 65-66, 121-175; Ali Fuat Bilkan, Fakihler ve Sofuların Kavgası 17. Yüzyılda Kadızâdeliler ve Sivâsîler (İstanbul: İletișim Yayınları, 2019), 15, 65, 115-166; Aydın Tonga, Osmanlı'nın Paralel Devleti Kadızadeliler (İstanbul: Doğu Kitabevi, 2017), 114-116, 135-173; Cağfer Karadaş, "Sivâsîler-Kadızâdeliler Olayı ve İnanç Boyutu", İlim ve Kültür Tarihinde Sivâsîler Ulusal Sempozyumu Tebliğleri 30 Nisan-1Mayıs 2010 Sivas, TSO Konferans Salonu (2011), 107, 110-115, 118; Cengiz Gündoğdu, "XVII. Yüzyılda Tekke-Medrese Münâsebetleri Açısından Sivâsîler - Kadızâdeliler Mücâdelesi", ILAM Araștırma Dergisi 3/1 (Ocak-Haziran 1998), 37-72; Ferhat Koca, "Osmanlılar Dönemi Fıkıh Tasavvuf İlişkisi: Fakılar İle Sofular Mücadelesinin Tarihi Serüveni", Gazi Üniversitesi Çorum İlahiyat Fakültesi Dergisi 1/1 (Çorum 2002/1), 85-87, 106. Cengiz Gündoğdu, "Sivâsî, Abdülmecid", Türkiye Diyanet Vakfı İslâm Ansiklopedisi (İstanbul: TDV Yayınları, 2009), 37/286-287; Kalaycl, Osmanlı Sünniliği, 250-251; Karadaș, "SivâsîlerKadızâdeliler Olayı ve İnanç Boyutu”, 114-115; Baz, Kadızadeliler Sivasiler Tartışması, 80-82; Bilkan, Fakihler ve Sofuların Kavgası, 101-102, 103-105.

7 Sivâsîler hareketinin önde gelen temsilcileri sırasıyla şu șahsiyetlerdir: Harekete ismini veren Abdülmecîd Sivâsî Efendi (öl. 1049/1639), Abdülehad Nûrî Efendi (öl. 1061/1651) ve Niyâzî-i Mısrî (öl. 1105/1694). bk. Semiramis Çavuşoğlu, "Kadızâdeliler", 14/100-102; Kalaycı, Osmanlı Sünniliği, 211, 213, 215, 240-244, 245-267; Baz, Kadızadeliler Sivasiler Tartışması, 35, 53-54, 6768, 80-87; Bilkan, Fakihler ve Sofuların Kavgası, 101-113.

8 Mehmet İpşirli, "Çivizâde Muhyiddin Mehmed Efendi", Türkiye Diyanet Vakfi İslâm Ansiklopedisi (İstanbul: TDV Yayınları, 1993), 8/348-349; Osman Cengiz, 16. Yüzyıl Osmanlı Düşüncesinin Kaynakları Civizâde - Ebusu'ûd - Birgivî (İstanbul: Ketebe Yayınları, 2018), 59-65, 113-128, 153 178, 189-247, 307-374, 379-381; Koca, “Osmanlılar Dönemi Fıkıh Tasavvuf İlișkisi”, 91, 97-98.

9 İbrâhim el-Halebî̀nin (İbrâhim b. Muhammed el-Halebî), Muhyiddîn İbnü'l-Arabî hakkındaki görüșleri için Ni'metü'z-zerî‘a fî nusrati'ş-șerî‘a, nșr. Alî Rızâ b. Abdullah b. Alî Rızâ (Riyâd: Dâru'lMesîr, 1419/1998) ve Tesfíhü'l-gabî fí tenzîhi İbn Arabî, nşr. Ebü'l-Berâ' Alî Rızâ b. Abdullah b. Alî Rızâ el-Medenî (Kâhire: Dârü'l-Meâric, 1429/2008) adlı eserlerine bakılabilir. Ayrıca bk.: Şükrü Selim Has, "Halebî İbrâhim b. Muhammed", Türkiye Diyanet Vakfi İslâm Ansiklopedisi (İstanbul: TDV Yayınları, 1997), 15/231; Kalaycı, Osmanlı Sünniliği, 218-229; a.mlf., "Birgivî Mirasının Toplumsal ve Metinsel Taşıyıcıları", 435, 438-439; Koca, "Osmanlılar Dönemi Fıkıh Tasavvuf İlişkisi", 98-99.

10 Emrullah Yüksel, "Birgivî", Türkiye Diyanet Vakfi İslâm Ansiklopedisi (İstanbul: TDV Yayınları, 1992), 6/192; Çavuşoğlu, "Kadızâdeliler", 24/100; Kalaycı, Osmanlı Sünniliği, 229-245; Karadaş, "Sivâsîler-Kadızâdeliler Olayı ve İnanç Boyutu", 114-115, 116.

11 Ali el-Kârî̀nin (Ali b. Sultân Muhammed el-Kârî), Muhyiddîn İbnü’l-Arabî hakkındaki görüșleri için șu eserlerine bakılabilir: er-Red ale'l-kâilîn bi vahdeti'l-vücûd nşr. Ali Rıza b. Abdullah b. Ali Rıza (Beyrut: Dârü'l-Me'mûn li't-Türâs, 1415/1995) (Vahdet-i Vücud, çev. Harun Ünal, İstanbul: Gümüș Ofset, 1995); Risâle fî vahdeti'l-vücûd (Mecmûatü resâil fî vahdeti'l-vücûd adlı mecmûanın içinde) (İstanbul 1294), 52-114; Risâle fí tefâvuti'l-mevcûdât (Berlin Ktp., 1639, 3369); Ferrü'lavn mimmen yeddaî (min müddeaî) îmâne (îmâni) Fir'avn (Süleymaniye Ktp., Esad Efendi, 1186), vr. 7-35; (Mecmûatü resâil fî vahdeti'l-vücûd adlı mecmûanın içinde) (İstanbul 1294), 115-163; Edilletü mu'tekadi Ebî Hanîfete'l-A'zam fì (hakkı) ebeveyi'r-Rasûl aleyhi's-salâtü ve's-selâm, nşr. Meşhûr Hasen Selmân (Medine: Mektebetü'l-Gurabâi'l-Eseriyye, 1413/1993). ayrıca bk. Ahmet Özel, "Ali el-Kârî", Türkiye Diyanet Vakfi İslâm Ansiklopedisi (İstanbul: TDV Yayınları, 1989), 2/403; Cafer Karadaș, "Alî el-Kârînnin Hayatı, Selef Akîdesine Dönüş Çabası ve Eserleri", Uludağ Üniversitesi İlahiyat Fakültesi Dergisi 5/5 (Bursa 1993), 290-299; Kalaycl, Osmanlı Sünniliği, 256264. Ali el-Kârî, Birgivî'den haberdardır. Zira Ali el-Kârî, et-Tarîkatü'l-Muhammediyye'yi gördüğünde kaleme aldığı ifade edilen methiyesinde Birgivî’yi "imamımız ve şeyhimiz" olarak niteler ve bu eserin içeriğinin yoldan sapma ve bid'at olduğunu söyleyenleri ise cahillikle suçlar. Manzûme fî medhi't-Tarîkati'l-Muhammediyye li'l-Birgivî (Süleymâniye Ktp., Düğümlü Baba, 150), 
Münâvî12 (öl. 1031/1622) ve harekete ismini veren Kadıâde Mehmed Efendi13 (öl. 1045/1635) gibi Muhyiddîn İbnü’l-Arabî karşıtı ulemâdır. ${ }^{14}$ Kendisi Bayramî-HalvetîCelvetî bir sûfî olan Bursevî̀nin, ${ }^{15}$ kendisi gibi Bayramî-Halvetî olan Sivâsîler ${ }^{16}$ tarafında yer aldığını söylemek mümkün gözükmektedir. Nitekim Bursevî̀nin zaman zaman Kadızâdeliler hareketinin fikrî referanslarından ve büyüklerinden biri olarak görülen Birgivî Mehmed Efendi'nin ${ }^{17}$ Vasiyetnâme ve et-Tarîkatü'l-Muhammediyye adlı eserlerinde yer verdiği, bir kısmı aşağıda zikredilen bazı görüşlerine karşı çıkmış olması bu hususu destekler mâhiyettedir.18 16 . ve 17. yüzyıllarda Sivâsîler ve

vr. 1b-2a; (449), vr. 146b-147a. bk. Hüseyin Elmalı, "Birgivî Hakkında Mısır, Mekke ve Medine Âlimlerinin Söylediği Bazı Şiirler”, Imam Birgivî, ed. Mehmet Şeker (Ankara: Türkiye Diyanet Vakfı, 1994), 86-87, 94-96. Bu methiyenin Ali el-Kârî̀ye âidiyetine yönelik geniş değerlendirme için bk. Necmi Sarı, "Birgivî’yi Öven Manzûmelerin Kritiği", Balıkesirli Bir İslam Âlimi İmam Birgivî, ed. Mehmet Bayyiğit - Mehmet Özkan - Ahmet Ali Çanakcı - Asem Hamdy Abdelghany (Balıkesir: Balıkesir Büyükșehir Belediyesi Kültür Yayınları, 2019), 3/583-615.

12 Abdürraûf Münâvî, kendisine nispet edilen övgü içerikli manzûmesinde Birgivî”yi “zamanın, hatta tüm zamanların âlimi, Acem'de ve Arab'da İslam'ın șeyhi” olarak vasıflandırır. Birgivî'yi Öven Manzûmeler (Süleymâniye Ktp., Düğümlü Baba, 449), vr. 147b-148a. bk. Elmalı, "Birgivî Hakkında Mısır, Mekke ve Medine Âlimlerinin Söylediği Bazı Şiirler", 85-86, 94. Bu methiyenin Abdürraûf Münâvî̀ye âidiyetine yönelik geniş değerlendirme için bk. Sarı, "Birgivî’yi Öven Manzûmelerin Kritiği", 3/583-615.

13 Gündoğdu, "XVII. Yüzyılda Tekke-Medrese Münâsebetleri Açısından Sivâsîler - Kadı-zâdeliler Mücâdelesi", 40-41; Çavuşoğlu, "Kadızâdeliler", 24/100-101; Kalaycı, Osmanlı Sünniliği, 244-245, 248-254; Baz, Kadızadeliler Sivasiler Tartışması, 53-54; Bilkan, Fakihler ve Sofuların Kavgası, 61, 89; Tonga, Osmanlı'nın Paralel Devleti Kadızadeliler, 94, 112; Karadaș, "Sivâsîler-Kadızâdeliler Olayı ve İnanç Boyutu”, 115; Koca, “Osmanlılar Dönemi Fıkıh Tasavvuf İliş̧kisi”, 105-107.

14 Kadızâdeliler hareketinin önde gelen temsilcileri sırasıyla şu şahsiyetlerdir: Harekete ismini veren Kadızâde Mehmed Efendi (öl. 1045/1635), Üstüvânî Mehmed Efendi (öl. 1072/1661), Vânî Mehmed Efendi (öl. 1096/1685) ve damadı Feyzullah Efendi (öl. 1115/1703). bk. Çavuşoğlu, "Kadızâdeliler", 24/100-102; Kalaycı, Osmanlı Sünniliği, 245-276, 279-293; Baz, Kadızadeliler Sivasiler Tartışması, 28, 53-54, 67-80; Bilkan, Fakihler ve Sofuların Kavgası, 61-100; Tonga, Osmanlı́nın Paralel Devleti Kadızadeliler, 92-104, 105-133; Koca, “Osmanlılar Dönemi Fıkıh Tasavvuf İlișkisi", 105-107, 113.

15 Sarı, İsmail Hakkı Bursevînnin Șerhu Nuhbeti'l-Fiker Adlı Eserinin Tahkik ve Tahlili, 88-94; Zübeyir Akçe, İsmâil Hakkı Bursevî́nin Tuhfe-i Recebiyye Edlı Eseri (İnceleme-Metin) (Urfa: Harran Üniversitesi Sosyal Bilimler Enstitüsü, Doktora Tezi, 2008), 44-47; Seyit Avcı, Sûfilerin Hadis Anlayışı Bursevî Örneği (Konya: Ensar Yayıncılık, 2004), 25-27; Baz, Kadızadeliler Sivasiler Tartışması, 35-36, 87; Mustafa Celil Altuntaș, Osmanlı Döneminde Hadis İlmi (İstanbul: İstanbul Üniversitesi Sosyal Bilimler Enstitüsü, Doktora Tezi, 2018), 112.

16 Çavușoğlu, "Kadıâdeliler", 24/100-101; Kalaycı, Osmanlı Sünniliği, 211, 213, 215, 240-244, 245267; a.mlf., "Birgivî Mirasının Toplumsal ve Metinsel Taşıyıcıları", 445, 541; Baz, Kadızadeliler Sivasiler Tartışması, 35, 80-82; Koca, "Osmanlılar Dönemi Fıkıh Tasavvuf İlişkisi”, 105-106, 108113.

17 bk. Kâtib Çelebi, Mîzânu'l-hak, 162-164; Şeyhî Mehmed Efendi, Vakâyiu'l-fudalâ', Şekâiku Nu'mâniyye ve Zeyilleri, nşr. Abdülkadir Özcan (İstanbul: Çağrı Yayınları, 1989), 1/59-60; Turan Arslan, İmam Birgivî Hayatı Eserleri ve Arapça Tedrisatındaki Yeri (İstanbul: Seha Neşriyat, 1992), 69-76, 116-117; Huriye Martı, Birgivî Mehmet Efendi (Ankara: Türkiye Diyanet Vakfı Yayınları, 2011), 166-181; a.mlf., Osmanlı'da Bir Dâru'l-Hadîs Şeyhi Birgivî Mehmed Efendi (İstanbul: Dârulhadis, 2008), 173; Yüksel, Mehmed Birgivi'nin (929-981/1523-1573) Dinî ve Siyasî Görüşleri, 59-64; Kalaycı, Osmanlı Sünniliği, 229-245; a.mlf., "Birgivî Mirasının Toplumsal ve Metinsel Taşıyıcıları", 436, 442-443, 444, 448-449, 452; Çavuşoğlu, "Kadızâdeliler", 24/100; İbrahim Baz, Kadızadeliler Sivasiler Tartışması, 55, 63, 65, 77, 78, 129, 182, 183, 207; Bilkan, Fakihler ve Sofuların Kavgası, 70, 74-75, 79, 89; Tonga, Osmanlı'nın Paralel Devleti Kadızadeliler, 105, 108, 176, 177, 186; Koca, "Osmanlılar Dönemi Fıkıh Tasavvuf İlișkisi”, 105.

18 bk. Bursevî, Tamâmü'l-Feyz [Ramazan Muslu ve Ali Namlı, İsmâil Hakkı Bursevî ve Tamâmü'l-Feyz Adlı Eseri-I ve II, (İstanbul: Marmara Üniversitesi Sosyal Bilimler Enstitüsü, Yüksek Lisans Tezi, 1994)], 2/182. Birgivî’nin İbnü'l-Arabî̀ye Şeyh-i Ekber yerine Șeyh-i Ekfer diyerek onu şiddetle eleștirdiğini belirten Bursevî, buna rağmen asrının fazilet sahibi şahsiyetlerinden biri olarak 
Kadızâdeliler arasında cereyan eden Muhyiddîn İbnü'l-Arabî merkezli bu tartışmaların şu konularda yoğunlaştığı görülmektedir: Dinî bilginin kaynağı (zâhirbâtın ilmi) meselesi, vahdet-i vücûd görüşü, Firavun'un imanı meselesi, Hz. Peygamber'in anne ve babasının âhiretteki durumu, Hızır aleyhi's-selâm'ın kimliği ve hayatı meselesi, Hz. İbrahim'in babası Âzer'in iman üzere ölüp ölmediği meselesi, tegannî ile Kur'ân okumak, semâ', raks ve deverânın dindeki yeri, kandil gecelerine ait namazlar (berât ve regâib namazları). ${ }^{19}$

\section{Bursevî'nin Ali el-Kârî Hakkında Kullandığı İfadeler}

Bursevî’nin şerhin metninde Ali el-Kârî̀yi ima ederken kullandı̆̆ı ifadeler bir hayli fazladır. ${ }^{20}$ Bazı ifadeleri şunlardır: "Kim şöyle/şunu demişse/derse",21 "Denildi ki",22 "Şöyle denildiği gibi",23 "Vehmedildiği gibi/üzere",24 "Vehmedildiği/Vehmettiği gibi", 25 "Şöyle vehmedildiğinden dolayı değil", ${ }^{26}$ "Şunu/böyle söyleyenin sözü", ${ }^{27}$ "Bazılarının sözünden anlaşllan", 28 "Kim bunu şununla/böyle tefsîr etmişse",29 "Bazılarının şu sözüne gelince",30 "Bunun böyle oluşunu kim câiz görmüşse",31 "Ancak kim şöyle demişse", 32 "Bazıları bașka bir şart ziyadesinde bulundu",33 "Bazıları dedi ki”, 34 "Bazıları bunu böyle

gördüğü, Acem, Arap ve Rûm diyârlarının meşâhîr-i ulemâsından biri olmakla nitelediği Birgivî'den nakilde bulunmuștur. Bursevî, Tamâmü'l-Feyz, 1/130-131.

Bu tartışma konuları için bk. Ali el-Kârî, Șerhu Șerhi Nuhbeti'l-fiker, nșr. Muhammed Nizâr Temîm - Heysem Nizâr Temîm (Abdülfettâh Ebû Gudde'nin takdimiyle) (Beyrut: Dâru'l-Erkam b. Ebi'lErkam, ts.), 553; Bursevî, Manevî Ufuklar I Kitâbu'n-Necât, 222-226; a.mlf., Tamâmü'l-Feyz, 1/2324; 2/60-61, 107, 155, 182; Kâtib Çelebi, Mîzânu'l-hak, 40-161, 95-101, 162-164; a.mlf., Fezleke-i Kâtib Çelebi, 2/183; Naîmâ, Târîh-i Naîmâ, 6/219-220; Uzunçarşıll, Osmanlı Tarihi, 3(1)/354-366; Çavuşoğlu, "Kadızâdeliler", 24/100-102; Kalaycı, Osmanlı Sünniliği, 200-201, 202-214, 245-293; a.mlf., "Birgivî Mirasının Toplumsal ve Metinsel Taşıyıcıları", 438-439, 442-454; Namlı, Ísmâil Hakkı Bursevî, 24-26; Baz, Kadızadeliler Sivasiler Tartıșması, 65-66, 121-175; Bilkan, Fakihler ve Sofuların Kavgası, 15, 65, 115-166; Tonga, Osmanlı'nın Paralel Devleti Kadıadeliler, 114-116, 135-173; Cafer Karadaș, "Sivâsîler-Kadızâdeliler Olayı ve İnanç Boyutu”, 107, 110-115, 117-120; a.mlf., "Alî el-Kârî’nin Hayatı”, 290-299; a.mlf., “İsmail Hakki Bursevî”nin İtikadî Görüșleri”, Uludağ Üniversitesi İlahiyat Fakültesi Dergisi 8/8 (Bursa 1999), 266-268; Özel, "Ali el-Kârî", 2/403; Yusuf Șevki Yavuz - Cağfer Karadaș, "İsmâil Hakkı Bursevî İtikâdî Görüșleri", Türkiye Diyanet Vakfı İslâm Ansiklopedisi (İstanbul: TDV Yayınları, 2001), 23/108-110; Gündoğdu, "XVII. Yüzyılda Tekke-Medrese Münâsebetleri Açısından Sivâsîler - Kadı-zâdeliler Mücâdelesi", 37-72; Mehmet Karagöz, "Osmanlı Fikir Hayatında Kadızâdeliler Hareketi”, Türkler 11 (Ankara: Yeni Türkiye Yayınları, 2002), 65-148; Koca, “Osmanlılar Dönemi Fıkıh Tasavvuf İlişkisi”, 85-87, 106. Nitekim Necmi Sarı tarafindan İsmail Hakkı Bursevî́nin Șerhu Nuhbeti'I-Fiker Adlı Eserinin Tahkik ve Tahlili adıyla yapılan doktora çalışmasının ilgili dipnotlarında, Bursevînnin bu ifadelerle Ali elKârîyi kastettiği belirtilmiştir. Bursevî, Șerhu Nuhbeti'l-fiker (İnebey/BEYBEK, Genel, 35-37), vr. 1/4a; 1/60a; 1/75b; 1/173a; 1/196a; 2/26b; 2/36a.

Bursevî, Serhu Nuhbeti'l-fiker (İnebey), vr. 1/35a; 1/153b.

Bursevî, Şerhu Nuhbeti'l-fiker (İnebey), vr. 1/166a; 1/184a.

Bursevî, Șerhu Nuhbeti'l-fiker (İnebey), vr. 1/54b; 1/99a,b; 1/124b; 1/200a; 2/2b; 2/27a.

Bursevî, Șerhu Nuhbeti'l-fiker (İnebey), vr. 1/67b; 1/71b.

Bursevî, Serhu Nuhbeti'l-fiker (İnebey), vr. 1/112b.

Bursevî, Şerhu Nuhbeti'l-fiker (İnebey), vr. 1/94a; 1/107b.

Bursevî, Şerhu Nuhbeti'l-fiker (İnebey), vr. 1/96a.

Bursevî, Şerhu Nuhbeti'l-fiker (İnebey), vr. 1/108a.

Bursevî, Șerhu Nuhbeti'l-fiker (İnebey), vr. 1/116b; 1/210b-211a.

Bursevî, Şerhu Nuhbeti'l-fiker (İnebey), vr. 1/117a.

Bursevî, Serhu Nuhbeti'l-fiker (İnebey), vr. 1/175b.

Bursevî, Şerhu Nuhbeti'l-fiker (İnebey), vr. 1/40a.

Bursevî, Şerhu Nuhbeti'l-fiker (İnebey), vr. 1/139a; 1/189b; 1/194a; 1/197a; 2/31a; (Kasîdecizâde, Süleymâniye Ktp., 46), vr. 421a. 
zabtettiler",35 "Bazl ehl-i fen açlkça ifade etti ki",36 "Böylece şu söylenilen husus defedilmiş oldu",37 "Böylece şunu diyenin sözü", 38 "Bazılarının şu sözü", 39 "Şunu kim demişse", 40 "Bazı şârihler dedi ki". ${ }^{41}$

Alaycı bir üslupla Ali el-Kârî'den bahsederken kullandığı ifadeler de şunlardır: "O (Ali el-Kârî) asıl itibarıyla İbn Hacer'in sözünü anlamadı.,",2 "Bizde olan (ilim) onda (Ali el-Kârî̀de) yoktur.", 43 "O (Ali el-Kârî) boș söz söyledi."44

Bursevî'nin hakaret içeren ifadelerinden bazıları ise şunlardır: "Çünkü bazı ahmaklar",45 "Bazı illet (hastalık) ehli", 46 "O (Ali el-Kârî) öyle bir tekellüf etti ki, ağız onu sümkürüyor. Tıpkı acı zehir gibi.", 47 "Bazı evhâm sahipleri”, 48 "İnsanların, öyle olmadığı halde kendisine güvendiği bazı kimselerin (Ali el-Kârı̂’nin) tercih ettiği gibi." 49

Nadiren de olsa Bursevî̀nin ima içeren bir ifade kullanmadan Ali el-Kârî̀ye reddiye verdiği görülmektedir. ${ }^{50}$

\section{Bursevî̀nin Ali el-Kârî̀ye Karşı Takındığı Olumsuz Tavrın Sebepleri}

Bursevî̀nin şerhin metninde Ali el-Kârîye karşı takındığı bu olumsuz tavrı, o dönemdeki nakil geleneğiyle veya Ali el-Kârî̀nin şerhinin ismini zikretmeye ihtiyaç bırakmayan şöhretiyle açıklamak mümkün değildir. Zira Bursevî'nin şerhinde Ali elKârî'den bahsederken kullandığı üslup yukarıda geçtiği gibi imalı ve alaycı hatta hakaret içeren bir üsluptur.

Yukarıdaki tartışma konularından hareketle Bursevî'nin Ali el-Kârî̀ye karşı takındığı bu olumsuz tavrı anlamamızı sağlayacak bazı muhtemel sâiklere değinmek yerinde olacaktır. Bu sâikler şunlardır:

\subsection{Ali el-Kârî’nin Muhyiddîn İbnü'l-Arabî Eleștirisi}

Ali el-Kârî'nin kelâmcıların yanısıra sûfiyyeden aşırı gidenleri, özellikle de Muhyiddîn İbnü'l-Arabî'yi (öl. 638/1240) eleştirmesi, hatta daha da ileri giderek onu küfürle itham etmesi. ${ }^{51}$ Ali el-Kârî̀nin, İbnü'l-Arabî eleștirisinin temelinde şu hususlar bulunmaktadir:

\footnotetext{
35 Bursevî, Şerhu Nuhbeti'l-fiker (İnebey), vr. 1/201a.

36 Bursevî, Şerhu Nuhbeti'l-fiker Kasîdecizâde, vr. 352b.

37 Bursevî, Şerhu Nuhbeti'l-fiker (İnebey), vr. 1/198a.

38 Bursevî, Şerhu Nuhbeti'l-fiker (İnebey), vr. 1/203a.

39 Bursevî, Şerhu Nuhbeti'l-fiker (İnebey), vr. 1/204a; 2/13b.

$40 \quad$ Bursevî, Şerhu Nuhbeti'l-fiker (İnebey), vr. 2/3a.

41 Bursevî, Şerhu Nuhbeti'l-fiker (Kasîdecizâde), vr. 368a; 417a.

42 Bursevî, Şerhu Nuhbeti'l-fiker (İnebey), vr. 1/78a.

43 Bursevî, Șerhu Nuhbeti'l-fiker (İnebey), vr. 1/108a

44 Bursevî, Şerhu Nuhbeti'l-fiker (İnebey), vr. 1/175b.

45 Bursevî, Şerhu Nuhbeti'l-fiker (İnebey), vr. 1/155b.

46 Bursevî, Şerhu Nuhbeti'l-fiker (İnebey), vr. 1/157b.

47 Bursevî, Şerhu Nuhbeti'l-fiker (İnebey), vr. 1/173a

48 Bursevî, Şerhu Nuhbeti'l-fiker (İnebey), vr. 1/177a; (Kasîdecizâde), vr. 116a.

49 Bursevî, Şerhu Nuhbeti'l-fiker (İnebey), vr. 2/25b.

50 bk. Bursevî, Şerhu Nuhbeti'l-fiker (İnebey), vr. 1/160b; 173b; (Kasîdecizâde), vr. 355a

51 Özel, "Ali el-Kârî”, 2/403.
} 
a. Dinî bilgiye kaynak olarak Kitap ve Sünnet dışında ilhâm, keşif, rüya, yakaza ve insilâh gibi bașka yollar kabul eden görüșe eleștirisi. İbnü'l-Arabî ve Gazzâlî gibi birçok sûfînin başvurduğu bu metodu ${ }^{52}$ yanlış bulan Ali el-Kârî, doğru yolun ancak Kitap, Sünnet ve icmâya dayanan yol olduğunu, onun dışındaki yolların ise sorunlu olduğunu belirtmiştir. ${ }^{53}$ Başta Şerhu Şerhi Nuhbeti'l-fiker adlı eseri olmak üzere hemen hemen bütün eserlerinde edille-i şer'iyye'yi kitap, sünnet, icmâ ve klyastan ibaret gören Ali el-Kârîn4, mutasavvıfların bu konudaki görüşlerine şiddetle karşı çıkmıştır. ${ }^{55}$ Örneğin Şerhu Şerhi Nuhbeti'l-fiker adlı eserinde keșif ve ilhâmın dinî ilimlerin tahsilinde delil olamayacağı hususunu ${ }^{56}$ İbn Hacer'in "İctihâd eseri olmayan haberlerde de sahâbeyi bunlara vâkıf kılan Hz. Peygamber'den başkası olamaz." ifadesini açıklarken şöyle dile getirmektedir: "Keşif ve ilhâma gelince, bunlarda yanılma ihtimali bulunduğundan dolayı her ikisi de araştırmanın dışındadır." 57

Bu hususta İbnü'l-Arabî ve Gazzâlî çizgisinde olan Bursevî'nin bu konulara yönelik görüşlerine birçok çalışmada ayrıntılı bir şekilde değinilmiştir. ${ }^{58}$

b. Vahdet-i vücûd felsefesine reddiyesi. ${ }^{59}$ Ali el-Kârî bu gayeyle er-Red ale'lkâilîn bi vahdeti'l-vücûd adında bir risâle kaleme almıştır. ${ }^{60}$ Bu risâle, İbnü'l-Arabî'nin Fusûsu'l-hikem adlı eserine reddiyedir. Ali el-Kârî yirmi dört görüşünden dolayı İbnü'l-Arabî̀yi şiddetli bir şekilde eleştirir hatta tekfir eder. Ali el-Kârî başka eserlerinde de bu hususa ișaret eder.61

52 Bu görüș için bk. Değaş b. Şebîb el-Acmî, İbn Arabî akîdetuhu ve mevklfu ulemâi'l-müslimîn minhu, 174-177; Abdullah Aydınl, Doğuş Devrinde Tasavvuf ve Hadis (İstanbul: Seha Neşriyat, 1986), 8992; Mustafa Kara, Tasavvufve Tarikatlar Tarihi (İstanbul: Dergâh Yayınları, 1985), 135-140; Cafer Karadaș, İbn Arabînin İtikadî Görüșleri (İstanbul: Beyan Yayınları, 1997), 53-55; a.mlf., "Muhyiddin İbn Arabî'nin İtikâdı", Tasavvuf: İlmî ve Akademik Araştırma Dergisi (İbnü'l-Arabî Özel Sayısl-1) 9/21 (2007), 68-70; a.mlf., “İsmail Hakki Bursevî”nin İtikadî Görüşleri”, Uludă̆ Üniversitesi İlahiyat Fakültesi Dergisi 8/8 (Bursa 1999), 266; a.mlf., "Sivâsîler-Kadızâdeliler Olayı ve İnanç Boyutu", 117, 118.

53 Karadaș, "Alî el-Kârî̀nin Hayatı", 292.

54 Ali el-Kârî, Șerhu Șerhi Nuhbeti'l-fiker, 220, 382-383, 406, 443, 447, 497, 675, 782.

55 Özel, "Ali el-Kârî”, 2/403; Kalaycı, Osmanlı Sünniliği, 280.

56 Ali el-Kârî'nin bu konu hakkındaki görüșü için bk. Avcı, Sûfilerin Hadis Anlayışı, 166-167.

57 Ali el-Kârî, Şerhu Şerhi Nuhbeti'l-fiker, 553.

58 bk. Avcı, Sûfilerin Hadis Anlayıșı Bursevî Örneği, 96-143; Sarı, İsmail Hakkı Bursevî̀nin Şerhu Nuhbeti'l-Fiker Adlı Eserinin Tahkik ve Tahlili, 241-279.

59 İbnü'l-Arabî'nin bu görüşünün eleştirisi için bk. Kalaycı, Osmanlı Sünniliği, 202-214; Ömer Nasuhi Bilmen, Büyük Tefsir Tarihi Tabakatü'l-Müfessirîn (İstanbul: Diyanet İşleri Reisliği Yayınları, 1960), 2/504.

60 Ali el-Kârî, er-Red ale'l-kâilîn bi vahdeti'l-vücûd, nşr. Ali Rıza b. Abdullah b. Ali Rıza (Beyrut: Dârü'lMe'mûn li't-Türâs, 1415/1995) (Vahdet-i Vücud, çev. Harun Ünal, İstanbul: Gümüș Ofset, 1995). Halil İbrahim Kutlay bu kitabı Reddü'l-Fusûs ismiyle verirken (Halil İbrahim Kutlay, el-İmâm Alî el-Kârî ve eseruhu fí ilmi'l-hadîs [(Beyrut: Dârü'l-Beşâiri'l-İ́slâmiyye, 1408/1987), 121-122)], Cağfer Karadaş Mecmûatü resâil fî vahdeti'l-vücûd (İstanbul 1294, 52-114) adlı mecmûaya itimaden Risâle fî vahdeti'l-vücûd olarak isimlendirmektedir. Karadaş, "Alî el-Kârî̀nin Hayatı", 292.

61 bk. Ali el-Kârî, Șemmü'l-avârız fĩ zemmi'r-Revâfız, nşr. Meşhûr Hasen Selmân (Ammân: ed-Dârü'lEseriyye, 2008), 53-56, 140; a.mlf., Ferrü'l-avn mimmen yeddaî (min müddeaî) îmâne (îmâni) Fir'avn (Mecmûatü resâil fî vahdeti'l-vücûd adlı mecmûanın içinde) (İstanbul 1294), 139; a.mlf., el-Mukaddimetü's-sâlime fí havfi'l-hâtime, nşr. Meşhûr Hasen Selmân (Beyrut: el-Mektebü'l-İslâmî - Ammân: Dâru Ammâr, 1409/1989), 31-33; a.mlf., et-Tecrîd fí i'râbi kelimeti't-tevhîd ve mâ yeteallaku bi ma'nâhâ mine't-temcîd, nşr. Meşhûr Hasen Selmân (Beyrut: el-Mektebü'l-İslâmî Ammân: Dâru Ammâr, 1411/1991), 32. 
c. Firavun'un ölmeden önce iman ettiği görüşüne ${ }^{62}$ reddiyesi. Ali el-Kârî'nin Ferrü'l-avn mimmen yeddaî (min müddeaî) îmâne (îmâni) Fir'avn adlı risâlesí3 Firavun'un iman ettiğini savunan Celâlüddîn Muhammed ed-Devvânî̀nin (öl. 908/1502) Risâle fî îmâni Fir'avn adlı eserine ${ }^{64}$ reddiye mâhiyetinde yazılan bir şerhtir. ${ }^{65}$ Eserde Firavun'un iman ettiğini savunan Muhyiddîn İbnü'l-Arabîî6 ve onun savunucusu ed-Devvânî şiddetle eleştirilmiștir. ${ }^{67}$ Ali el-Kârînnin bu hususta İbn Teymiyye'den (öl. 728/1328) etkilendiğini söylemek mümkündür. ${ }^{68}$ Nitekim İbn Teymiyye bu konu hakkında Risâle fi'r-reddi alâ İbn Arabî fî da'vâ îmâni Fir'avn adında bir risâle yazmıștır.69

Bursevî, "Fakat azabımızı gördükleri zaman imanları kendilerine bir fayda vermeyecektir. Allah'ın kulları hakkında süregelen âdeti budur. İște o zaman kâfirler hüsrana uğrayacaktır." 70 mealindeki âyetten hareketle genel olarak ye's halindeki imanı ${ }^{71}$ özel olarak da ye's halinde iman eden Firavun'un imanını ${ }^{72}$ kabul etmemek suretiyle takipçisi olduğu İbnü'l-Arabî'ye aykırı düşmüştür. ${ }^{73}$

Bu meselenin Muhyiddîn İbnü'l-Arabî’ye nispetinde ihtilaf bulunmaktadır. Firavun'un imanının sahih olduğu görüşünün Muhyiddîn İbnü'l-Arabî̀ye nispeti hakkında geniş bilgi için bk. Kâtib Çelebi, Mîzânu'l-hak, 95-101; Süleyman Aydın, "Kur'ân ve Sünnet Işığında Firavun'ın İmânı Meselesi", Hitit Üniversitesi İlahiyat Fakültesi Dergisi 13/26 (Çorum 2014/2), 126-129, 131-134, 144-145; Mahmut Çınar, "Ye's ve Be's Halinde İmânın Hükmü: Firâvun'un İmânı Örneği", Marmara Üniversitesi İlahiyat Fakültesi Dergisi [İstanbul Yüksek İslam Enstitüsü Dergisi] [MÜiFD] 41 (İstanbul 2011/2), 124, 126-127, 127-133, 140, 141-142; Fikret Soyal, Celâleddin edDevvânînnin Firavun'un İmânı Konusundaki Görüşleri ve Ali el-Kârî̀nin Eleștirisi (İstanbul: İstanbul Üniversitesi Sosyal Bilimler Enstitüsü, Yüksek Lisans Tezi, 2004), 50-56, 90; Ömer Faruk Harman, "Firavun”, Türkiye Diyanet Vakfi İslâm Ansiklopedisi (İstanbul: TDV Yayınları, 1996), 13/120-121; Ali Namlı, "XVIII. Yüzyılda İbnü'l-Arâbî'yi Tartışmak: İsmâil Hakkı Bursevî'nin Firavun'un İmanı Meselesine Yaklaşımı", Osmanlı'da İlm-i Tasavvuf (İstanbul: İsar Yayınları, 2018), 477-483, 488. (Süleymaniye Ktp., Esad Efendi, 1186), vr. 7-35; (Mecmûatü resâil fî vahdeti'l-vücûd adlı mecmûanın içinde) (İstanbul 1294), 115-163.

64 Devvânî, Celâlüddîn Muhammed ed-Devvânî, Risâle fî îmâni Fir'avn (Süleymaniye Ktp., Pertevniyal, 929). Bu eser hakkında bilgi için bk. Harun Anay, "Devvânî", Türkiye Diyanet Vakfı İslâm Ansiklopedisi (İstanbul: TDV Yayınları, 1994), 9/260; Kalaycı, Osmanlı Sünniliği, 207, 257 258.

Mustafa Akman, "Firavun'un İmânı Konusunda Celâleddin ed-Devvânî ile Ali el-Kârî Arasındaki Polemik", II. Uluslararası El Ruha Sosyal Bilimler Kongresi Tam Metin Kitabı, 9-11 Şubat 2018, Şanlıurfa (Șanlıurfa 2018), 15-20. bk. Bursevî, Rûhu'l-beyân, 4/84 (Yûnus 10/91 âyetinin tefsiri). İbnü'l-Arabî'nin bu görüșünün eleștirisi için bk. Bursevî, Rûhu'l-beyân, 4/83-85 (Yûnus 10/91-92 âyetlerinin tefsiri); Süleyman Aydın, "Kur'ân ve Sünnet Ișığında Firavun'un İmânı Meselesi”, Hitit Üniversitesi İlahiyat Fakültesi Dergisi 13/26 (Çorum 2014/2), 121-148; Mahmut Çınar, "Ye's ve Be's Halinde İmânın Hükmü: Firâvun'un İmânı Örneği", M.Ü. İlâhiyat Fakültesi Dergisi [İstanbul Yüksek İslam Enstitüsü Dergisi] [MÜíFD] 41 (İstanbul 2011/2), 121-142; Kalaycl, Osmanlı Sünniliği, 207, 249, 251, 258. Anay, "Devvânî", 9/260; Kalaycı, Osmanlı Sünniliği, 257-258.

68 Bilmen, Büyük Tefsir Tarihi, 2/504.

69 İbn Teymiyye, Ahmed b. Abdülhalîm el-Harrânî, Risâle fi'r-reddi alâ İbn Arabî fí da'vâ îmâni Fir'avn (Câmiu'r-resâil içinde), nșr. Muhammed Reșâd Sâlim (Cidde: Dârü’l-Medenî, 1405/1984), 1/203216. Ayrıca bk. İbn Teymiyye, Mecmû'u'l-fetâvâ, cem ve tertîb: Abdurrahmân b. Muhammed b. Kâsım en-Necdî (Riyâd: Dâru Âlemi'l-Kütüb, 1412/1991), 2/362-380. el-Gâfir (el-Mü'min) 40/85. Ayrıca bk. Yûnus 10/90-92.

71 Bursevî, Rûhu'l-beyân, 8/245-248 (el-Gâfir/el-Mü'min 40/85 âyetinin tefsiri); a.mlf., Kitâbü'lHitâb (İstanbul 1256), 61, 67.

72 Bursevî, Rûhu'l-beyân, 4/82-85 (Yûnus 10/90-92 âyetlerinin tefsiri).

73 Bu konu hakkında ayrıntılı bilgi için bk. Rûhu'l-beyân, 8/245-248 (el-Gâfir/el-Mü'min 40/85 âyetinin tefsiri); 4/82-85 (Yûnus 10/90-92 âyetlerinin tefsiri); a.mlf., Kitâbü'l-Hitâb, 61, 67; a.mlf., Ferâhu'r-rûh (Şerhu'l-Muhammediyye) (İstanbul 1294), 1/373-374; a.mlf., Tamâmü'l-Feyz, 1/134; 
d. Ali el-Kârî'nin Hz. Peygamber'in anne ve babasının âhiretteki durumuna ilișkin olarak ${ }^{74}$, Ebû Hanîfe'ye (öl. 150/767) nispeti tartışmalı olan el-Flkhu'l-ekber adlı eserde ${ }^{75}$ geçen "Rasûlullah sallallâhu aleyhi ve sellem'in anne ve babası küfür üzere öldüler, amcası ve Hz. Ali radiyallâhu anh'ın babası Ebû Tâlib de kâfir olarak öldü."76 şeklindeki ifadeye dayanarak Ebeveyn-i Rasûl'ü kâfir görmesi. Ali el-Kârî, Ebû Hanîfe'nin Hz. Peygamber'in ebeveyninin mü'min olmadıklarına dair görüșünü desteklemek, Süyûtî (öl. 911/1505) ve İbn Kemâl (Kemalpaşazâde), ${ }^{77}$ (öl. 940/1534) gibi karşıt görüş sâhibi âlimlere reddiye vermek maksadıyla Edilletü mu'tekadi Ebî Hanîfete'l-A'zam fî (hakkı) ebeveyi'r-Rasûl aleyhi's-salâtü ve's-selâm ${ }^{78}$ adında bir risâle kaleme almıştır.79 Bu risâlede Kemalpaşazâde'nin "Özetle bu konu, akâid konularından değildir." 80 sözüne karşı "Muazzam muteber İmâm Ebû Hanîfe'nin elFlkhu'l-ekber adlı eserinin sonlarında zikrederek akâidin konusu saydığı bir mesele nasıl akâid konusu olmaz?"81 diye itiraz ederek Ebû Hanîfe'ye olan bağlılığını ortaya

a.mlf., el-Vâridât (İnebey/BEYBEK, Genel, 67), vr. 87b. Ayrıca bk. Namlı, “XVIII. Yüzyılda İbnü'lArâbî̀yi Tartışmak", 483-488, 488-489.

Bu konu hakkında geniş bilgi için bk. Kâmil Miras, Sahîh-i Buhârî Muhtasarı Tecrîd-i Sarîh Tercemesi ve Şerhi (Ankara: Diyânet İşleri Başkanlığı Yayınları, 1985), 4/533-552. Bu konu hakkında ayrıntılı bilgi için bk. Kevserî, Muhammed Zâhid el-Kevserî, "Ebû Hanîfe'nin elÂlim ve'l-müteallim adlı eserine yazdığı mukaddime" (Kâhire 1368/19499, 6-7; Mustafa Akçay, “Hz. Peygamber'in Anne-Babasının (Ebeveyn-i Resûl) Dînî Konumuna Dâir Ebû Hanîfe'ye Atfedilen Görüș Etrafındaki Tartışmalar”, Sakarya Üniversitesi İlahiyat Fakültesi Dergisi 19 (Sakarya 2009), 1-27; a.mlf., "Ebeveyn-i Resul Tartışmalarında Zahidu'l-Kevserî'nin Yeri ve Bir Hatanın Düzeltilmesi, Uluslararası Düzceli M. Zâhid Kevserî Sempozyumu 24-25 Kasım 2007, 591602; Kalaycı, Osmanlı Sünniliği, 262-265; Karadaș, "Sivâsîler-Kadızâdeliler Olayı ve İnanç Boyutu”, 117, 119-120; Abdullah Demir, “Osmanlı Âlimlerinin Ebû Hanîfe'nin Akâid Risâlelerini Konu Edinen Eserleri = The Works of Ottoman Scholars on Abu Hanifa's Article of Faith", Türkiye Araștırmaları Literatür Dergisi Türkiye'de İslami Ilimler: Kelâm ve Mezhepler Tarihi II 14/28 (İstanbul 2016), 173-175; Şerafettin Gölcük - Adil Bebek, “el-Fıkhü'l-ekber”, Türkiye Diyanet Vakfi İslâm Ansiklopedisi (İstanbul: TDV Yayınları, 1995), 12/544-546.

76 Ali el-Kârî, Minahu'r-ravzi'l-ezher fî şerhi'l-Fıkhi'l-ekber (Şerhu Kitâbi'l-Flkhi'l-ekber), nșr. Vehbî Süleymân Gâvcî (Nâșirin et-Ta'lîku'l-müyesser alâ șerhi'l-Fıkhi'l-ekber'i ile birlikte) (Beyrut: Dârü'l-Beşâiri'l-İslâmiyye, 1419/1998), 310-211; Ebü'l-Müntehâ, Ahmed b. Muhammed elMağnisâvî, Şerhu'l-Fıkhi'l-ekber (İstanbul 1278), 45; Beyazîzâde, Ahmed b. Hasen el-Bosnevî, elUsûlü'l-münîfe li'l-İmâmi Ebî Hanîfe, nşr. İlyas Çelebi (İstanbul: M.Ü. İlahiyat Fakültesi Vakfi Yayınları, 1416/1996), 143 (İmam Azam Ebu Hanife'nin İtikadî Görüşleri, çev. İlyas Çelebi, İstanbul: M.Ü. İlahiyat Fakültesi Vakfı Yayınları, 1996, 143).

77 Kemalpaşazâde (Șemseddin Ahmed) bu konu hakkında Risâle fî hakkı ebeveyi'n-Nebî adında bir risâle yazmıștır. Bu risâle Ahmed Cevdet tarafından Resâl-i İbn Kemâl adıyla 1316/1898 yılında İstanbul İkdâm Matbaasında risâleler mecmûası içinde yedinci risâle olarak neşredilmiştir (7791). Ali el-Kârî, Kemalpaşazâde'nin bu risâlede ortaya koyduğu görüșlere müstakil bir başlık altında reddiye vermiștir. bk. Edilletü Mu'tekadi Ebî Hanîfete'l-A'zam fî Ebeveyi'r-Rasûl aleyhi'ssalâtü ve's-selâm, nşr. Meşhûr Hasen Selmân (Medine: Mektebetü'l-Gurabâi'l-Eseriyye, 1413/1993), 137-146. Kemalpaşazâde'nin bu risâlesi hakkında geniş bilgi için bk. Mustafa Akçay, Ebeveyn-i Resûl Risâleleri (İstanbul: Yeni Akademi Yayınları, 2005), 257; a.mlf., "Kemâl Paşazâde ve "fî Hakkı Ebeveyni'n-Nebî" Adlı Risâlesinin Tahlil ve Değerlendirmesi", EKEV Akademi Dergisi -Sosyal Bilimler-, 9/22 (Erzurum 2005), 127-142; Salih Kesgin, Hadisleri Anlama Sorunu (İstanbul: İSAM Yayınları, 2019), 119, 121-122. Gurabâi'l-Eseriyye, 1413/1993). bk. Demir, “Osmanlı Âlimlerinin Ebû Hanîfe'nin Akâid Risâlelerini Konu Edinen Eserleri", 209. Ali el-Kârî̀nin bu konu hakkındaki görüşünün uzun bir değerlendirmesi için bk. Kutlay, el-İmâm Alî el-Kârî, 106-112; Akçay, Ebeveyn-i Resûl Risâleleri, 102-188, 214-226. İbn Kemâl, Risâle fí hakkı ebeveyi'n-Nebî, 91. krş. Ali el-Kârî, Edilletü Mu'tekadi Ebî Hanîfete'l$A^{\prime} z a m, 141$.

81 Ali el-Kârî, Edilletü Mu'tekadi Ebî Hanîfete'l-A'zam, 141. 
koymuş ve konuyla ilgilenen birçok âlimin aksine konuyu itikâdî temel bir mesele kabul etmiştir. 0, Ebû Hanîfe'nin mezkur sözünü şöyle açıklamıştır: "İmâmın bu ifadesi, Ebeveyn-i Rasûl'ün iman üzere öldüklerini veya küfür üzere ölüp daha sonra Hz. Peygamber'in her ikisi için Allah'a dua ettiğini, bunun üzerine Allah'ın ikisini de diriltip iman ettiklerini ve bu iman üzere öldüklerini söyleyenlere karşı bir reddiyedir. Hiç kuşkusuz bu söz, Hz. İmâm tarafından söylenmiştir. Bu konuda maksat, zannî rivâyetle değil, ancak kat'î delille anlaşllabilir. Çünkü bu husus, bir itikâd konusu olduğu için zanniyyâtla amel edilmez, zayıf âhâd hadisler ve vehmiyyât kabilinden rivâyetlerle yetinilemez. Hiç şüphesiz bilinen en temel ilke şudur ki insanoğlundan hiç kimse Kitap, mütevâtir sünnet, icmâ-ı ümmetten delil sâbit olmadıkça başka bir kimse hakkında cennetlik olduğu veya cehennemlik/kâfir olduğu hakkında hüküm veremez." 82 Ali el-Kârî diğer bir eseri olan Șerhu'l-Fıkhi'l-ekber'de Ebû Hanîfe'nin bu ifadesi hakkında şu açıklamada bulunmuştur: "İmâmın bu ifadesi, Ebeveyn-i Rasûl'ün iman üzere öldüklerini veya küfür üzere ölüp daha sonra Allah'ın ikisini de diriltip iman ettiklerini ve iman makâmında ruhlarını teslim edip öldüklerini söyleyenlere karşı bir reddiyedir. Ben bu mesele hakkında müstakil bir risâle yazıp, Süyûtî'nin (öl. 911/1505) Hz. Peygamber'in ebeveyninin diriltileceği ve Hz. Peygamber'e iman ettikten sonra tekrar âhirete intikal ettirileceklerine dair hadislere (ihyâ hadisleri) ${ }^{83}$ dayanan görüşünü84 takviye etmek amacıyla üç risâlesinde ${ }^{85}$ zikrettiği hususları Kitap, sünnet, klyas ve icmâ-ı ümmet'ten topladığım üzerinde ittifak edilen delillerle çürüttüm. Bu meselede garip olan husus, Hanefîlerden bazı câhil kimselerin İmâm'ın bu sözüyle ilgili açıklamalarımdan dolayı beni ayıplayıp kınamaları, hatta bu sözü İmâm-ı A'zam'ın makâmına lâyık görmemeleridir. Oysa onların bu yaptığıyla "Mushaftan Allah Teâlâ'nın "Sonra (Rabbiniz) Arș'a istivâ etti"86 buyruğunu silmeyi arzu ettim." diyen sapkın Cehm b. Safvân'ın (öl. 128/745-46) ifadesi arasında hiçbir fark yoktur. Yine onların bu tavrıyla diğer bir sapkın olan Ahmed b. Ebî Duâd el-Kâdî’nin (öl. 240/854) Halife Me'mûn'dan (öl. 218/833) Kâbe'nin örtüsünün üzerine “O'nun benzeri hiçbir şey yoktur. O, hakklyla işitendir, hakklyla görendir.”87 yazılmasını istemesi ve Râfızîler'in en büyügünün

82 Ali el-Kârî, Edilletü Mu'tekadi Ebî Hanîfete'l-A'zam, 62-63.

83 İhyâ hadislerine ilişkin kısa bir değerlendirme için bk. Bünyamin Erul, "Uydurma Rivayetlerde Peygamber Tasavvuru". İslâm’ın Anlaşılmasında Sünnetin Yeri ve Değeri, Kutlu Doğum Sempozyumu 2001 (Ankara: Türkiye Diyanet Vakfı Yayınları, 2003), 425-427; Kesgin, Hadisleri Anlama Sorunu, 117-122.

84 Süyûtî'nin bu konu hakkındaki görüşlerinin kısa bir değerlendirmesi için bk. Kesgin, Hadisleri Anlama Sorunu, 117-121.

85 Ali el-Kârî, Edilletü Mu'tekadi Ebî Hanîfete'l-A'zam fî Ebeveyi'r-Rasûl aleyhi's-salâtü ve's-selâm adlı eserini Süyûtî'nin üç risâlesinde zikrettiği hususlara cevap olarak yazdığını belirtir. bk. Ali el-Kârî, Minahu'r-Ravzi'l-Ezher, 310; a.mlf., Mirkâtü'l-mefâtîh șerhu Mişkâti'l-Mesâbîh, nşr. Cemâl Aytânî (Beyrut: Dârü'l-Kütübi'l-İlmiyye, 1422/2001), 4/217; a.mlf., Şerhu'ş-Şifâ fî hukûki'l-Mustafâ (Beyrut: Dârü'l-Kütübi'l-İlmiyye, 1421/2000), 1/605, 651; 2/447. Süyûtî'nin (Celâluddîn esSüyûtî) bu konu hakkında te'lif ettiği eser sayısı altıdır: Mesâlikü'l-Hunefâ fî Vâlideyi'l-Mustafâ, edDerecü'l-Münîfe fi'l-Âbâi'ş-Șerîfe, el-Makâmetü's-Sündüsiyye fi'n-Nisbeti'l-Mustafaviyye, et-Ta'zîm ve'l-Minne fí Enne Ebevey Rasûlillâh fi'l-Cenne, Neşrü'l-'Alemeyni'l-Münîfeyn fî İhyâi'l-Ebeveyni'şŞerîfeyn, es-Sübülü'l-Celiyye fi'l-Âbâi'l-Aliyye. Bu risâlelerin hepsi er-Resâilü't-tis'u içinde ilk altı risâle olarak basılmıștır (Haydarâbâd: Matbaatü Dâireti'l-Meârifi'l-Osmâniyye, 1380/1961). Bu risâleler hakkında ayrıntılı bilgi için bk. Mustafa Akçay, Ebeveyn-i Resûl Risâleleri, 189-214; Miras, Sahîh-i Buhârî Muhtasarı, 4/539-548; Kesgin, Hadisleri Anlama Sorunu, 117. 
'İçerisinde Hz. Ebû Bekir'in (öl. 13/634) sıfatı ${ }^{88}$ bulunan mushaftan ben ber'îyim' sözü arasında da hiçbir fark yoktur." ${ }^{99}$ Ali el-Kârî aynı hususa başka eserlerinde de muhtelif vesilelerle temas etmiştir. ${ }^{90}$

Süyûtî gibi Bursevî de Hz. Peygamber'in ebeveyninin diriltileceği ve Hz. Peygamber'e iman ettikten sonra tekrar âhirete intikal ettirilecekleri görüşündedir. ${ }^{91}$

e. Hızır aleyhi's-selâm'ın kimliğine yönelik olarak onun velî olduğu görüşüne reddiyesi. ${ }^{92}$ Ali el-Kârî̀ye göre Hızır aleyhi's-selâm velî değil, nebîdir/peygamberdir ve hâlâ hayattadır, ölmemiştir. ${ }^{33}$ Ali el-Kârî bu görüşünü desteklemek için Keşfü'l-hidr an emri'l-Hıdr adında ${ }^{94}$ bir risâle kaleme almıștır. ${ }^{95}$

Allah'ın Hz. Ebû Bekir'i övdüğü şu âyete ișaret edilmektedir: “Eğer siz ona (Peygamber'e) yardım etmezseniz, (biliyorsunuz ki) inkâr edenler onu iki kişiden biri olarak (Mekke'den) çıkardıkları zaman, ona bizzat Allah yardım etmişti. Hani onlar mağarada bulunuyorlardı. Hani o arkadașına, "Üzülme, çünkü Allah bizimle beraber" diyordu. Allah da onun üzerine güven duygusu ve huzur indirmiş, sizin kendilerini görmediğiniz birtakım ordularla onu desteklemiş, böylece inkâr edenlerin sözünü alçaltmıştı. Allah’ın sözü ise en yücedir. Allah, mutlak güç sahibidir, hüküm ve hikmet sahibidir." et-Tevbe 9/40.

89 Ali el-Kârî, Minahu'r-ravzi'l-ezher, 310-311. bk. Kalaycı, Osmanlı Sünniliği, 264.

Ali el-Kârî, Semmü'l-avârız, 51-53; a.mlf., el-Mukaddimetü's-sâlime fì havfi'l-hâtime, 18; a.mlf., Mirkâtü'l-mefâtîh, 4/216-217; a.mlf., Şerhu'ş-Şifâ fî hukûki'l-Mustafâ, 1/605, 651; 2/447; a.mlf., Edilletü Mu'tekadi Ebî Hanîfete'l-A'zam, 62-63.

91 Bursevî, Rûhu'l-beyân, 1/219-220 (el-Bakara 2/119 âyetinin tefsiri); 3/546-548 (et-Tevbe 9/116 âyetinin tefsiri); $7 / 237$ (el-Ahzâb 33/57 âyetinin tefsiri). bk. Yusuf Șevki Yavuz - Cağfer Karadaș, "İsmâil Hakkı Bursevî İtikâdî Görüșleri", Türkiye Diyanet Vakfi İslâm Ansiklopedisi (İstanbul: TDV Yayınları, 2001), 23/109. Bursevî Tefsîr'inde az önce işaret edilen yerlerde sadece Hz. Peygamber'in ebeveyninin değil aynı zamanda fetret ehlinden gördüğü Hz. Peygamber'in amcası Ebû Tâlib ve dedesi Abdülmuttalib'in de öldükten sonra diriltilecekleri ve Hz. Peygamber'e iman ettikten sonra tekrar âhirete intikal ettirilecekleri görüșündedir. Rûhu'l-beyân'ın Türkçe çevirisinde el-Bakara 2/119 âyetinin tefsirinde büyük eksiklik vardır. Muhalif görüșe hiç yer verilmemiştir. bk. Rûhu'l-Beyân Kur'an Meâli ve Tefsiri, çev., Heyet (İstanbul: Erkam Yayınları, 2011-2016), 1/582-583.

92 Hızır'ın velî olup hâlâ hayatta olduğu görüşünün eleştirisi için bk. İbn Kayyim el-Cevziyye, Muhammed b. Ebî Bekr ez-Zürâî ed-Dımaşkî, el-Menâru'l-münîf fi's-sahîhi ve'd-da'îf, nşr. Abdurrahmân b. Yahyâ el-Mu'allimî-Mansûr b. Abdülazîz es-Simârî (Riyâd: Dâru'l-Âsıme, 1416/1996), 50 56, No: 11; İbn Hacer, Ahmed b. Alî el-'Askalânî, ez-Zehrü'n-nadr fî nebe'i (hâli)'lHadr, nșr. Salâhuddîn Makbûl Ahmed (Kuveyt: Mektebetü Ehli'l-Eser, 1425/2004) (Rivâyet İlimleri Açısından Hızır'ın Nübüvvet ve Hayat Meselesi, çev. M. Beşir Eryarsoy, İstanbul: Ümmülkura Yayınları, 2006); Ali Akpınar, "Şemseddin Sivasîye Göre Hz. Hızır'ın Kimliği / Mahiyeti”, Osmanlılar Döneminde Sivas: Sempozyum Bildirileri, 21-25 Mayıs 20072 (2007), 121136; Muhittin Uysal, "Tespit ve Yorum Bakımından Hızır'la İlgili Haberler”, Selçuk Üniversitesi Illahiyat Fakültesi Dergisi 10 (Konya 2000), 337-366. Ali el-Kârî, Minahu'r-ravzi'l-ezher, 182, 340-341; a.mlf., er-Red ale'l-kâilîn bi vahdeti'l-vücûd, 6263.

Halil İbrahim Kutlay (el-İmâm Alî el-Kârî, 125) ve Cağfer Karadaș ("Alî el-Kârî’nin Hayatı", 292) bu risâleyi Keş̧ü'l-Hidr fî Hâli'l-Hıdr ismiyle kaydetmiş olmalarına rağmen Ali el-Kârî risâlesinin isminin Keșfü'l-Hidr an Emri'l-Hıdr olduğunu belirtmektedir. Ali el-Kârî, el-Esrâru'l-merfûa fi'lahbâri'l-mevzûa (el-Mevzûâtü'l-kübrâ), nșr. Muhammed b. Lütfî es-Sabbâğ (Beyrut: el-Mektebü'lİslâmî, 1406/1986), 422-423. Eser, el-Hazer fî emri'l-Hadır adıyla basılmıștır.

95 (Süleymaniye Ktp., Fatih, 5327); (Süleymaniye Ktp., Esad Efendi, 1446); (Ârif Hikmet, 82/24, 211/9); el-Hazer fî emri'l-Hadır, nşr. Muhammed Hayr Ramazan Yûsuf (Dımaşk: Dârü'l-Kalem Beyrut: Dârü'ş-Şâmiyye, 1411/1991). 
Bursevî de Hızır aleyhi's-selâm'ın bâtınî bilgilere göre hareket eden bir peygamber olduğunu ve hâlâ hayatta olduğunu savunmaktadır. ${ }^{96}$ Nitekim Bursevî birkaç kez Hızır aleyhi's-selâm ile görüştüğünü söylemektedir. ${ }^{97}$

f. Hz. İbrahim'in babası Âzer'in iman üzere öldüğü görüşüne reddiyesi.98 Ali el-Kârî ulemânın kâhir ekseriyetle kabul ettiği gibi Hz. İbrahim'in babası Âzer'in küfür üzere öldügü görüşündedir.

Bursevî de bu görüştedir. ${ }^{99}$ Ali el-Kârî, Edilletü Mu'tekadi Ebî Hanîfete'l-A'zam fî Ebeveyi'r-Rasûl aleyhi's-salâtü ve's-selâm adlı eserinde aksi görüş sahiplerine müstakil bir başlık altında reddiye vermiştir.100

g. Tegannî ile Kur'ân okumanın, zikir esnasında semâ', raks ve deveran etmenin ${ }^{101}$ câiz olduğu görüşünü eleştirmesi. Ali el-Kârî bu görüşü eleştirmek ve bu konuda izlenmesi gereken orta yolu göstermek maksadıyla tespit edebildiğimiz

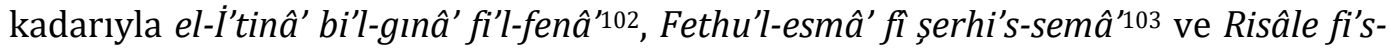
semâ' ve'l-gınấ ${ }^{\prime 104}$ adında üç risâle kaleme almıștır.

Bursevî gerek tegannî ile Kur'ân okumayı gerekse zikir esnasında semâ', raks ve deverân etmeyi câiz görür, muhalifleri eleştirir.105

96 Bursevî, Rûhu'l-beyân, 5/269-275 (el-Kehf 18/65 âyetinin tefsiri); a.mlf., Kitâbü'n-Netîce, nşr. Ali Namlı-İmdat Yavaș (İstanbul: İnsan Yayınları, 1997), 1/459-463; a.mlf., Manevî Ufuklar II Kitâbu'l-Hitâb, sadeleștiren İ. Turgut Ulusoy (İstanbul: Hisar Yayınları, 1983), 332-334; M. Necmettin Bardakçı, "İsmail Hakkı Bursevî̀nin Musa-Hızır Kıssası Yorumunun İlim-Marifet Uygunluğu Açısından Değerlendirmesi”, Süleyman Demirel Üniversitesi İlahiyat Fakültesi Dergisi 5 (Isparta 1998), 97.

97 Bursevî, Kitâbü'n-Netîce, 2/84; a.mlf., Kitâbu's-Silsileti'l-Celvetiyye (Silsile-i Celvetiyye, Silsilenâmei Celvetî) (Millet Ktp., Şer'iye, 1040), vr. 83b (İlyas Efendi, İsmail Hakkı Bursevi'nin Kitâbu'sSilsileti'l-Celvetiyye'si, İstanbul: Marmara Üniversitesi Sosyal Bilimler Enstitüsü, Yüksek Lisans Tezi, 1994), 83b. krș. Sarı, Ísmail Hakkı Bursevî́nin Șerhu Nuhbeti'l-Fiker Adlı Eserinin Tahkik ve Tahlili, 54, 91; a.mlf., "Kendi Dilinden İsmâil Hakkî Bursevî’nin Hayatı ve Şahsiyeti”, KTÜ İlahiyat Fakültesi Dergisi 2/3 (Trabzon 2015), 152.

98 Kadir Gömbeyaz, "Vânî Mehmed Efendi'nin Hz. İbrahim'in Babası ve Ebeveyn-i Resûl Hakkındaki Görüşleri”, Ulusal Vânî Mehmed Efendi Sempozyumu 7-8 Kasım 2009, Kestel-Bursa -Bildiriler(Bursa 2011), 205-211; Kalaycı, Osmanlı Sünniliği, 207. Bursevî, İbnü'l-Arabî'den farklı olarak ulemânın kâhir ekseriyetle kabul ettiği gibi Hz. İbrahim'in babası Âzer'in küfür üzere öldüğü görüşündedir. bk. Bursevî, Rûhu'l-beyân, 3/57-59 (el-En'âm 6/74 âyetinin tefsiri); 3/545-546 (et-Tevbe 9/114 âyetinin tefsiri).

$100 \quad$ bk. 134-137. Ayrica bk. 120-122.

101 Bu konu hakkındaki tartışmalar için bk. Kalaycı, Osmanlı Sünniliği, 248-249, 251, 269; Karadaş, "Sivâsîler-Kadızâdeliler Olayı ve İnanç Boyutu", 117.

102 Eser hakkında bk. Halil İbrahim Kutlay, el-İmâm Alî el-Kârî, 128; Karadaş, "Alî el-Kârî”nin Hayatı”, 295.

103 Eser hakkında bk. Halil İbrahim Kutlay, el-İmâm Alî el-Kârî, 132-133; Karadaş, "Alî el-Kârînnin Hayatı", 296. Eser Şinasi Kaya tarafından Ne Ifrat Ne Tefrit Musıkî Hakkında Tam Tespit adıyla Türkçe'ye çevrilmiştir (Samsun 1414/1993).

104 Eser için bk. (Süleymâniye Ktp., Esad Efendi, 1690/28).

105 bk. Bursevî, Manevî Ufuklar I Kitâbu'n-Necât, 222-226; a.mlf., Temâmü'l-Feyz, 1/23-24; II, 60-61, 107, 155, 182. Ayrıca bk. Mehmed Ali Aynî, İsmail Hakkı Bursalı ve Rûhu'l-Beyan Müellifi, nşr. İsmail Dervişoğlu (İstanbul: Büyüyen Ay, 2013), 267-271. 
h. Kandil gecelerine ait namazların özellikle de berât, regâib ve miraç namazlarının ${ }^{106}$ meşru olduğu görüşünü eleștirmesi107. Ali el-Kârî bu görüşü eleştirmek ve bu konuda izlenmesi gereken orta yolu göstermek amaciyla $e l-E d e b$ fi Receb, ${ }^{108}$ Risâle fimâ yeteallaku bi leyleti'n-nısfi min Şa'bân ve Leyleti'l-kadr ${ }^{109}$ ve elMevridü'r-revî fi'l-mevlidi'n-nebevîi110 adında üç risâle kaleme almıştır.

Bursevî, Berât, Regâib ve Kadir gibi mübarek gecelerde bu gecelere has namaz kılınacağını savunur ve bu namazlara karşı çıkanlara ve özellikle de Nevevî̀ye (öl. 676/1277) şiddetli eleştirilerde bulunur. ${ }^{111}$

\subsection{Ali el-Kârî'nin Bid'at ve Hurafelerle Mücadelesi}

Dönemindeki bid'at ve hurafelerle yoğun bir şekilde mücadele eden ve bundan dolayı asrın müceddidi olarak anılan ${ }^{112}$ Ali el-Kârî̀nin, itikâdî konuları ele alış bakımından Selef'in yöntemini benimsemesi. ${ }^{113}$ Ahmet Özel onun bu yönüne "İtikâdî konularda Selefiyye'nin görüşlerini benimsemiş, bu sebeple kelâm ve tasavvuf konularındaki aşırı temâyüllere karşı çıkmıştır"114 diyerek dikkat çekmiştir.

el-Fıkhu'l-ekber üzerine yazdığı şerh Kadızâdeliler çevresinde yaygın olan Ali el-Kârî, Kur'ân ve Sünnet'ten uzaklaşmış, felsefeyle ve bid'at ehlinin söz ve görüşleriyle kirlenmiş kelâma karşı çıkmıştır. Şerhin girişinde kelâm ilminin gaye ve önemine dikkat çeken Ali el-Kârî, devamında felsefenin neden haram olduğunu, felsefeyi haram gören âlimlerin sözleriyle temellendirmeye çalışır. Ali el-Kârî, Selef âlimlerin kelâm ilmine neden karşı çıktıklarını yedi madde halinde zikretmiş, bu sebepler arasında, kelâmcıların İslam'ın asıllarından yüz çevirip boş şeylerle uğraşmalarını, insanları şaşkınlığa, sapıklığa, şüphe ve tereddüde sürükleyip düşürmelerini, rey ve mücerred akıl ile hüküm vermelerini, âyet ve hadisleri bırakarak filozofların ve onlara tâbi olan sefîhlerin sözlerine kulak asmalarını saymıştır. ${ }^{115} \mathrm{Bu}$ sebeplerden dolayı Ali el-Kârî̀ye göre mantık ilmi gibi felsefe ilmiyle de uğraşmak selef ulemâsının ve haleften muteber müfessirlerin ekserisinin icmâı ile haramdır. 1160 ayrıca, felsefe ve mantık ilmiyle uğraşmanın haram olduğuna dair bir kitap telif ettiğini ve bu kitapta imâmların felsefeyle uğraşmanın haram olduğu hususunda ortaya koydukları delilleri zikrettiğini ifade etmektedir. ${ }^{117}$ Abdullah

\footnotetext{
106 Bu konu hakkındaki tartışmalar için bk. Kalaycı, Osmanlı Sünniliği, 248-249, 254, 269; Karadaş, "Sivâsîler-Kadızâdeliler Olayı ve İnanç Boyutu", 117.

107 Ali el-Kârî, el-Edeb fî Receb, nşr. Meşhûr Hasen Selmân (Beyrut: el-Mektebü'l-İslâmî, 1411/1991), 42-44, 47-48, 48-49. Eser hakkında bk. Halil İbrahim Kutlay, el-İmâm Alî el-Kârî, 154; Karadaş, "Alî el-Kârînnin Hayatı", 299. Eser daha önce geçtiği gibi Meşhûr Hasen Selmân'ın tahkikiyle aynı adla yayımlanmıştır. Eser hakkında bk. Halil İbrahim Kutlay, el-İmâm Alî el-Kârî, 158.

110 Eser hakkında bk. Halil İbrahim Kutlay, el-İmâm Alî el-Kârî, 146; Karadaş, "Alî el-Kârî̀nin Hayatı”, 298.

111 Bursevî̀nin bu namazlar hakkındaki görüşü için bk.: Avcı, Sûfilerin Hadis Anlayışı Bursevî Örneği, 78-87; Sarı, İsmail Hakkı Bursevî́nin Şerhu Nuhbeti'l-Fiker Adlı Eserinin Tahkik ve Tahlili, 227-237. Kutlay, el-İmâm Alî el-Kârî, 95-96; Kalaycı, Osmanlı Sünniliği, 257.

Kutlay, el-İmâm Alî el-Kârî, 97.

Özel, "Ali el-Kârî", 2/403.

Ali el-Kârî, Minahu'r-ravzi'l-ezher, 29-42.

Ali el-Kârî, Minahu'r-ravzi'l-ezher, 30.

Ali el-Kârî, Minahu'r-ravzi'l-ezher, 30. Bk. Kalaycı, Osmanlı Sünniliği, 280.
} 
Demir, Ali el-Kârî’nin itikâdî konularda Selefî bir duruş benimsediğini belirtirken,,118 bu konuda müstakil bir çalışması olan Cağfer Karadaş onun bu yönüne "Ancak Ali elKârî’nin selefiliği kendine özgüdür. $\mathrm{Bu}$, selefilikte Ebû Hanîfe çizgisi diye adlandırabilir."119 diyerek işaret etmektedir. Bu bağlamda Ali el-Kârî̀nin, İbn Teymiyye (öl. 728/1328) ile öğrencisi İbn Kayyim el-Cevziyye'nin (öl. 751/1350) ilmî kudretlerini takdir etmesi ve onları savunması, ${ }^{120}$ onun Selefî ulemânın görüşlerine sıcak baktığını göstermesi açısından önemlidir. ${ }^{121}$

\section{Sonuç}

Tam mânâsıyla Muhyiddîn İbnü'l-Arabî hayranı olan Bursevî, onun gibi vahdet-i vücûd fikrini şiddetle savunmuştur. Firavun'un imanı meselesi, Hızır aleyhi's-selâm'ın kimliği ve hayatı meselesi ve Hz. İbrahim'in babası Âzer'in iman üzere ölüp ölmediği meselesi dışında başta yukarıdaki tartışma konuları dahil olmak üzere hiçbir meselede Muhyiddîn İbnü'l-Arabî’ye muhalefet ettiğine dair dördüncü bir örneğe rastlayabilmiş değiliz. Bursevî̀nin tahlil ettiği pek çok fikrin asıllarını Muhyiddîn İbnü'l-Arabî'nin eserlerinde bulmak mümkündür.122

Kendisi mutaassıb bir Hanefî123 ve sûfî olan Bursevî̀nin, Ali el-Kârîye karşı takındığı bu olumsuz tavrı, Ali el-Kârî̀nin bahsi geçen tartışma konularının ekserisinde ortaya koyduğu görüşleriyle ${ }^{124}$ Muhyiddîn İbnü'l-Arabî karşıtı cephe olan Kadızâdeliler tarafında yer almasına bağlamanın doğru olmadığı kanaatindeyiz. Zira Bursevî'nin Nuhbetü'l-fiker șerhi dışındaki diğer bazı eserlerinde "Şeyh Ali el-Kârî Şerhu'n-Nuhbe'de dedi ki"125, "Ali el-Kârînin Şerhu'n-Nuhbe'sinde böyledir"126, "Şerhu'n-Nuhbe'de olduğu gibi"127 şeklindeki ifadeleriyle Ali el-Kârî ve eseri Şerhu'nNuhbeti'l-fiker'den (Şerhu Şerhi Nuhbeti'l-fiker) ismen söz ettiğini tesbit etmiş

118 Demir, “Osmanlı Âlimlerinin Ebû Hanîfe’nin Akâid Risâlelerini Konu Edinen Eserleri”, 195.

119 Karadaș, "Alî el-Kârî̀nin Hayatı”, 291.

120 bk. Ali el-Kârî, Mirkâtü'l-mefâtîh, 8/216-217. krş. Özel, "Ali el-Kârî”, 2/403; Bilmen, Büyük Tefsir Tarihi, 2/504; M. Sait Özervarlı, İbn Teymiyye'nin Düşünce Metodolojisi ve Kelâmcllara Eleștirisi (İstanbul: İSAM Yayınları, 2008), 167.

121 Karadaș, "Alî el-Kârî̀nin Hayatı", 291. Bu konu hakkında geniş bilgi için bk. Karadaș, "Alî elKârî̀nin Hayatı", 290-291.

122 bk. Avcı, Sûfilerin Hadis Anlayışı, 298.

123 Bursevî'nin Hanefî mezhebine bağlılığını gösteren sözleri için bk. Bursevî, Şerhu Nuhbeti'l-fiker (İnebey), vr. 3/158b; (Kasîdecizâde), vr. 412a; a.mlf., Manevî Ufuklar I Kitâbu'n-Necât, 113-115. Bu bağlamda İmâm Ebû Hanîfe, ashâbı ve ehli mezhebine karșı așırı derecede mutaassıp dediği Hatîb el-Bağdâdî'yi şiddetle yerer. bk. Bursevî, Şerhu Nuhbeti'l-fiker (İnebey), vr. 1/13b; (Kasîdecizâde), vr. 8a. Ayrıca bk. Bursevî, Serhu Nuhbeti'l-fiker (İnebey), vr. 1/15b; 1/20b; 2/100b; 2/190b-191a; 3/158a-b; (Kasîdecizâde), vr. 13a; 213b-214a; 278a; 412a; a.mlf., Șerh-i Pend-i Attâr (İstanbul 1287), 71 (Tuba Onat Çakıroğlu, İsmail Hakkı Bursevî’nin “Şerh-i Pend-i Attâr" (Attâr'ın Pendnâmesi'nin Açılklaması) Adlı Eseri Üzerine Bir İnceleme ve Attâr'ın Pendnâme'si Ile Karşılaştırılması (Ankara: Hacettepe Üniversitesi Sosyal Bilimler Enstitüsü, Doktora Tezi, 2012), vr. 28a-28b (s. 131-132); a.mlf., Manevî Ufuklar I Kitâbu'n-Necât, 113-115; a.mlf., Ferâhu'rrûh (Şerhu'l-Muhammediyye), 2/4; a.mlf., Kitâbü'n-Netîce, 2/226.

124 bk. Bilmen, Büyük Tefsir Tarihi, 2/504.

125 Bursevî, Furûku Hakkî, 33, 66. Ali el-Kârî̀nin sözü için bk. Ali el-Kârî, Şerhu Şerhi Nuhbeti'l-fiker, 226, 643.

126 Bursevî, Rûhu'l-beyân, 8/545; a.mlf., Furûku Hakkî, 244. Ali el-Kârî’nin sözü için bk. Ali el-Kârî, Şerhu Şerhi Nuhbeti'l-fiker, 471; 575-576.

127 Bursevî, Rûhu'l-beyân, 10/44. Ali el-Kârî'nin sözü için bk. Ali el-Kârî, Şerhu Şerhi Nuhbeti'l-fiker, 445. 
bulunmaktayız. Buna ilâveten Bursevî'nin muhtelif eserlerinde, Ali el-Kârî̀nin Şerhu Şerhi Nuhbeti'l-fiker'i dışındaki diğer eserlerinden bahsederken "Şeyh Ali el-Kârînnin Şerhu'l-Menâsik'de şöyle dediğini gördüm"128, "Bu latîfe (incelik) Ali el-Kârî'nin elMukaddimetü'l-Cezeriyye'ye yaptığı șerhte zikredilmiștir"129 örneklerinde olduğu gibi bazen müellif ve eser ismi birlikte, "Nitekim Tîbî kâil olmuş ve Alî el-Kârî dahi ona iktida etmiştir"130 örneğinde olduğu gibi bazen sadece müellif ismiyle, bazen de "elMefâtîh olarak isimlendirilen SSerhu'l-Mesâbîh'de böyledir"131, "el-Mefâtîh'de"132, "Şerhu'l-Mesâbîh'de böyledir"133, "el-Cezeriyye'nin şârihi dedi ki"134 şeklinde müellif ismi olmadan eser isimleriyle söz etmesi bu kanaatimizi destekler mâhiyettedir.

Bu kanaatimizi destekleyen diğer bir husus da Bursevî̀nin mezkur eserlerini te'lif ettiği tarihler dikkate alındığında, zaman içinde Ali el-Kârî hakkındaki düşüncelerinde olumludan olumsuz yöne veya olumsuzdan olumlu yöne doğru bir kayma olduğu ihtimalinin ortadan kalkmış olmasıdır.

Bursevî'nin Ali el-Kârî ve eserinin ismini bir kez dahi zikretmediği Şerhu Nuhbeti'l-fiker adlı eseri, yazıldığı tarih itibarıyla bu eserlerin en sonuncusu değildir. Bursevî Tekirdağ'da yazmaya başladığı fakat bitiremediği bu eserini 1129/1717 yılında Şam'da tamamlamıştır. ${ }^{135}$ Bu eserlerden Furûku Hakkî (1095/1684),136 Tamâmü'l-feyz fì bâbi'r-ricâl (1103/1692) ${ }^{137}$ ve Rûhu'l-beyân fî tefsîri'l-Kur'ân'ı (1096/1685-1117/1705) ${ }^{138}$ Şerhu Nuhbeti'l-fiker adlı eserinden önce yazmıștır.

128 Bursevî, Tamâmül-Feyz, 2/189.

129 Bursevî, Furûku Hakkî, 337.

130 Bursevî, Kırk Hadis Şerhi, nşr. Sami Erdem, arş. Hikmet Gültekin (İstanbul: İnsan Yayınları, 2005), 188 (İstanbul: Dâru't-Tıbâati'l-Âmire, 1317/1899, 38).

131 Bursevî, Furûku Hakkî, 277.

132 Bursevî, Furûku Hakkî, 291.

133 Bursevî, Furûku Hakkî, 300.

134 Bursevî, Rûhu'l-beyân, 6/512. Ayrica bk. 7/185. Bursevî bununla Ali el-Kârî'nin el-Minehu'lfikriyye bi șerhi'l-Mukaddimeti'l-Cezeriyye adlı eserini kastediyor (Kenarında Zekeriyyâ elEnsârî̀nin (öl. 926/1520) ed-Dekâiku'l-muhkeme fî șerhi'l-Mukaddimeti'l-Cezeriyye adlı eseriyle, Kâhire 1302).

135 Bursevî, Şerhu Nuhbeti'l-fiker (İnebey/BEYBEK, Genel, 37), vr. 212b. bk. Sâkıb Yıldız, "Türk Müfessiri İsmail Hakkı Burûsevi'nin Hayatı", Atatürk Üniversitesi İslâmî Illimler Fakültesi Dergisi 1 (Erzurum 1975), 117, 119; Naml, İsmâil Hakkı Bursevî, 189; a.mlf., "İsmâil Hakkı Bursevî Hazretlerinin Hayatı ve Eserleri”, Rûhu'l-Beyân Kur'an Meâli ve Tefsiri (İstanbul: Erkam Yayınları, 1432/2011), 1/27; İsmail Güleç, Mesnevî Șerhi Rûhü'l-Mesnevî -Mesnevî́nin İlk 748 Beytinin Şerhiİsmail Hakkî Bursevî (İstanbul: İnsan Yayınları, 2012), 119; Muslu, İsmail Hakkı Bursevî ve Temâmü'l-Feyz Adlı Eseri, 1/21; Altuntaș, Osmanlı Döneminde Hadis İlmi, 113. Bursevî, șerhinin asıl metni olan Nüzhetü'n-Nazar fí Tevdîhi Nuhbeti'l-Fiker'i, talebeliği zamanında 1083/1672'de istinsah etmiş ve kenarlarına yer yer notlar düşmüştür. Bursevî, Risâletü İbn Hacer fí ilmi'l-hadîs (İnebey/BEYBEK, Genel, 34), vr. 1a; 30a. bk. Namlı, İsmâil Hakkı Bursevî, 189.

136 Bursevî, Furûku Hakkî, 350. bk. Naml, İsmâil Hakkı, 167; a.mlf., "İsmâil Hakkı Bursevî Hazretlerinin Hayatı ve Eserleri”, Rûhu'l-Beyân Kur'an Meâli ve Tefsiri, 1/38; İsmail Güleç, İsmâil Hakkl Bursevî̀nin 'Rûhu'l-Mesnevî́sinin İncelenmesi (İstanbul: İstanbul Üniversitesi Sosyal Bilimler Enstitüsü, Doktora tezi, İstanbul 2002), 101.

137 Bursevî, Tamâmü'l-Feyz, 2/217. bk. Namlı, Ísmâil Hakkı Bursevî, 171; a.mlf., "İsmâil Hakkı Bursevî Hazretlerinin Hayatı ve Eserleri”, Rûhu'l-Beyân Kur'an Meâli ve Tefsiri, 1/29; Muslu, Ísmail Hakkı Bursevî ve Temâmü'l-Feyz Adlı Eseri, 1/25, 32; Güleç, İsmâil Hakkı Bursevî’nin 'Rûhu'l-Mesnevî'sinin Incelenmesi, 95.

138 Bursevî, Rûhu'l-beyân, 10/570; a.mlf., Min vâridâti'l-Fakîr eş-Şeyh İsmâîll Hakkî min evâhiri Zilhicce min seneti 1116 (Süleymâniye Ktp., Hâlet Efendi, 789), vr. 127b-128b; a.mlf., Kitâbü'n-Netîce, 2/429-430. Rûhu'l-beyân'ın telifinin bu kadar uzun sürmesinin sebepleri için bk. Bursevî, Min Vâridâti'l-Fakîr eș-Şeyh İsmâîl Hakkî, vr. 127b-128a. Ayrıca bk. Namlı, İsmâil Hakkı Bursevî, 179; 
Bursevî bu eserlerinin bir kısmında Ali el-Kârî ve eseri Şerhu'n-Nuhbeti'l-fiker'den (Şerhu Şerhi Nuhbeti'l-fiker) ismen söz ederken, diğer bir kısmında Ali el-Kârî'nin Şerhu Şerhi Nuhbeti'l-fiker'i dışındaki diğer eserlerinden bazen müellif ve eser ismi birlikte, bazen sadece müellif ismiyle, bazen de müellif ismi olmadan eser isimleriyle söz etmektedir.

Bursevî, Ali el-Kârî'den ismen bahsettiği Şerhu'l-Erbaîne hadîsen (Kırk Hadis Serhi) adlı eserini ise, Serhu Nuhbeti'l-fiker adlı eserinden 8 yıl sonra 1137/1724 yılı Muharrem ayı sonlarında (Ekim 1724) Bursa'da tamamlamıştır.139 Bu tarih Bursevî'nin ölüm tarihi olan 9 Zülkade 1137/20 Temmuz 1725'ten 10 ay gibi kısa bir süre önceye tekabül etmektedir. ${ }^{140}$ Bu nedenle Şerhu'l-Erbaîne hadîsen adlı eseri, bu eserler içinde en son yazdığı eseri olması nedeniyle Bursevî̀nin görüşlerinin tespitinde belirleyici bir özelliğe sahip olmaktadır.

Bursevî gibi ilmî hayatını başından sonuna kadar vahdet-i vücutçu bir çizgide geçiren bir sûfî için, zaman içinde Ali el-Kârî hakkındaki düşüncelerinde, Şerhu Nuhbeti'l-fiker'den önce yazdığı isimleri yukarıda mezkur eserlerindeki tavrından dolayı olumludan olumsuz yöne doğru bir kayma olduğunu söylemek ne kadar yanlışsa, Şerhu Nuhbeti'l-fiker'den sonra yazdığı Şerhu'l-Erbaîne hadîsen (Kırk Hadis Şerhi) adlı eserindeki tavrından dolayı olumsuzdan olumlu yöne doğru bir kayma olduğunu söylemek de o kadar yanlıştır. Zira Bursevî gibi ilim hayatının ilk dönemlerinden itibaren zengin bir kütüphaneden istifade ettiği anlaşılan bir ilmî kişiliğin, gerek eserleriyle gerekse görüşleriyle yaşadığı dönem ve sonrasında Osmanlı ilim câmiasında büyük bir etki bırakmış, hatta İbn Âbidîn (öl. 1252/1836),,141 Abdülhay el-Leknevî (1848-1886) ${ }^{142}$ ve diğer bazı Hanefî âlimlerin hicrî on birinci

a.mlf., "İsmâil Hakkı Bursevî Hazretlerinin Hayatı ve Eserleri", Rûhu'l-Beyân Kur'an Meâli ve Tefsiri, 1/40-41; a.mlf., "İsmâil Hakkı Bursevî̀nin Rûhu'l-beyân fì tefsîri'l-Kur'ân Adlı Tefsîri”, Türkiye Araștırmaları Literatür Dergisi 9/18 (İstanbul 2011), 368-369; Güleç, İsmâil Hakkı Bursevî́nin 'Rûhu'l-Mesnevî́sinin İncelenmesi, 109; Muslu, İsmail Hakkı Bursevî ve Temâmü'l-Feyz Adlı Eseri, 1/20; Yakup Çiçek, "İsmâil Hakkı Bursevî”, Îman Esaslarına Tasavvufî Bir Bakış (Şerh-u Şu'abi'l-Îmân) (İstanbul: Dârulhadis, 2000), 31-32.

139 Bursevî, Kırk Hadis Serhi, 528 (Dâru't-Tıbâati'l-Âmire baskısı, 303). bk. Naml, İsmâil Hakkı Bursevî, 204; a.mlf., "İsmâil Hakkı Bursevî Hazretlerinin Hayatı ve Eserleri", Rûhu'l-Beyân Kur'an Meâli ve Tefsiri, 1/27; Güleç, İsmâil Hakkı Bursevî'nin 'Rûhu'l-Mesnevî’sinin İncelenmesi, 120; Muslu, İsmail Hakkı Bursevî ve Temâmü'l-Feyz Adlı Eseri, 1/21-22.

$140 \quad$ Avcı, Sûfilerin Hadis Anlayışı Bursevî Örneği, 61.

141 İbn Âbidîn, Muhammed Emîn ed-Dımașkî, Tenbîhu'l-vülât ve'l-hukkâm alâ ahkâmi șâtimi hayri'lenâm ev ahadi's-sahâbeti'l-kiram (Mecmûatü resâil İbn Âbidîn içinde, 1/313-371) (İstanbul: Dersaâdet, 1325/1907), 1/368. krş. Ali el-Kârî, Şemmu'l-avârız fî zemmi'r-revâfiz, nşr. Meşhûr Hasen Selmân (Ammân: Dârü'l-Eseriyye, 1429/2008), 37 (nâşirin önsözü); Kutlay, el-İmâm Alî elKârî, 96; Özel, "Ali el-Kârî", 2/403.

142 Leknevî, Abdülhay el-Leknevî, et-Ta'lîkâtü’s-seniyye ale'l-Fevâidi'l-behiyye (el-Fevâidü'l-behiyye fî terâcimi'l-Hanefiyye ile birlikte), nşr. Muhammed Bedreddîn Ebû Firâs en-Na'sânî (Kâhire: Matbaatü's-Saâde, 1324/1906), 8-9 (1 nolu dipnot). krş. Ali el-Kârî, Şemmu'l-avârız fí zemmi'rrevâfiz, 36-37 (nâşirin önsözü); Kutlay, el-İmâm Alî el-Kârî, 95-96; Özel, "Ali el-Kârî", 2/403. 
asrın müceddidleri arasında saydıkları ${ }^{143}$ Ali el-Kârî gibi Hanefî mezhebine son derece bağlı büyük bir âlimin ${ }^{144}$ bu tür görüşlerinden haberdâr olmaması düşünülemez.

Öte yandan Bursevî’den (öl. 1137/1725) seksen küsür yll sonra vefat eden Âkifzâde'nin (öl. 1223/1808 veya 1232/1817), İstanbul müderrislerinden Bayburtlu İbrâhim Efendi'nin (öl. ?) bizzat gördügünü naklettiği Bursevî’ye ait bir risâlede; Bursevînnin vahdet-i vücutçu fikirlerinden dönüp bunlardan tevbe-istiğfâr ettiğini gösteren sözlerine yönelik naklini ${ }^{145}$ ilginç ve değerli bulmakla beraber, Bursevî'nin kendi eserleri başta olmak üzere Bursevî'den bahseden eserlerin hiçbirinde bu hususu destekleyecek bir bilgiye rastlayamadığımızı da özellikle ifade etmek isterim.

Bütün bu zikredilen hususlardan sonra Bursevî'nin Ali el-Kârî̀ye karşı takındığı bu olumsuz tavra neden olabileceğini düşündüğümüz tek bir sebep kalmaktadır ki o da Bursevî’nin kendi şerhinin, Ali el-Kârî̀nin şerhinin gölgesinde kalmasını istemediği için böyle bir yöntem ve üslup benimsemiş olabileceği ihtimalidir. Bursevî temel bir kaynak olarak başından sonuna kadar çok fazla istifade ettiği hatta intihal derecesine varacak derecede alıntılar yaptığı bu eserin bilinmesini özellikle istememiş olabilir. Bu yönüyle Bursevînnin șerhinin, hadis usûlü bilgileri açısından âdeta Ali el-Kârî̀nin şerhinin iyi bir hâş̧iyesi olduğu söylenebilir. ${ }^{146}$ Buradaki hâşiyeden kastımızın hadis literatüründe "Bir kitabın gerekli görülen yerlerine yapılan açılklamalar"147 şeklinde tarif edilen hâşiyeden ${ }^{148}$ daha genel anlamda kullanılan “'metin' ve 'kitap’ üzerine yapılmış, doğru ve yerinde anlamaya, ilmi muhafazaya, devamlılı̆̆ı sağlamaya ve malumatı olabildiğince kaydetmeye dönük, fonksiyonel ve katılımcı yoğun çabaların bir ürünü"149 olan hâşiye olduğunu

143 Hatta Ali el-Kârî̀nin kendisi de "tahdîs-i ni'met" kabilinden bu hususu bizzat dile getirmiștir. Ali el-Kârî, Şemmu'l-avârız fi zemmi'r-revâfız, 74-75. krş. İbn Âbidîn, Tenbîhu'l-Vülât ve'l-Hukkâm, 1/368; Ali el-Kârî, Şemmu'l-avârız fî zemmi'r-revâfız, 37 (nâşirin önsözü); Kutlay, el-İmâm Alî elKârî, 96; Özel, "Ali el-Kârî", 2/403. Bu konu hakkında geniș bilgi için bk. İbn Âbidîn, Tenbîhu'lVülât ve'l-Hukkâm, 1/368; Ali el-Kârî, Șemmu'l-avârız fî zemmi'r-revâfız, 36-37 (nâş̧irin önsözü); Kutlay, el-İmâm Alî el-Kârî, 95-96; Özel, "Ali el-Kârî", 2/403. Özel, "Ali el-Kârî", 2/403; Zübeyde Özben, "Hanefîler'in Mukaddime Temelli Hadis Usulü Literatürüne Katkısı", İslâm Araştırmaları Dergisi 36 (İstanbul 2016), 8.

145 Âkifzâde, Abdürrahîm b. İsmâil el-Amâsî el-Merzifonî, Kitâbü'l-Mecmû' fi'l-meșhûd ve'l-mesmû'. Milli Eğitim Bakanlı̆̆ı Çorum İl Halk Ktp., 27011, 245-246. [çev. Hikmet Özdemir (İstanbul: Özfa Matbaacllık, 1998), 299].

146 Nitekim Necmi Sarı tarafından İsmail Hakkı Bursevî’nin Şerhu Nuhbeti'l-Fiker Adlı Eserinin Tahkik ve Tahlili adıyla yapılan doktora çalışmasının ilgili dipnotlarında, bu hususlara işaret edilmiştir.

147 Abdullah Aydınlı, Hadis Istılahları Sözlüğü (İstanbul: M.Ü. İlahiyat Fakültesi Vakfı Yayınları, 2011), 114; Tevfik Rüştü Topuzoğlu, "Hâşiye", Türkiye Diyanet Vakfi İslâm Ansiklopedisi (İstanbul: TDV Yayınları, 1997), 16/419-420; Muhammed Emin Güller, İbn Kutluboğa'nın Nüzhetü'n-Nazar Hâşiyesinde İbn Hacer'e Yönelttiği Tenkidler (Tokat: Tokat Gazi Osmanpaşa Üniversitesi Sosyal Bilimler Enstitüsü, Yüksek Lisans Tezi, 2018, 29; Mehmet Ali Aysan, Mehmed et-Trabzonî’nin erRisâle fî Fenni Usûli'l-Hadîs: Hâșiye alâ Nüzheti'n-Nazar fî Tavdîhi Nuhbeti'l-Fiker Adlı Eseri ve Hadis Usûlüne Katkısı (Bayburt: Bayburt Üniversitesi Sosyal Bilimler Enstitüsü, Yüksek Lisans Tezi, 2019, 33-34.

148 Bu yönüyle hâşiye, şerhlerden "gerekli görülen yerler" ifadesiyle ayrılmaktadır. Sezai Engin, "Hadis Litaratüründe Hâşiyeler: Nuhbetü'l-fiker ve Nüzhetü'n-nazar Üzerine Yapılan Hâşiye Çalışmaları Bibliyografyası", Hadis ve Siyer Araştırmaları 1/1 (İstanbul 2015), 78.

149 İsmail Kara, İlim Bilmez Tarih Hatırlamaz Şerh ve Haşiye Meselesine Dair Birkaç Not (İstanbul: Dergâh Yayınları, 2014), 19; a.mlf., "Unuttuklarını Hatırla! Şerh ve Haşiye Meselesine Dair Birkaç Not", Dîvân Disiplinlerarası Çalışmalar Dergisi 15/28 (İstanbul 2010/1), 8-9. Daha ayrıntılı bilgi için bk. Kara, Illim Bilmez Tarih Hatırlamaz, 21-24; a.mlf., "Unuttuklarını Hatırla!”, 11-12; Güller, İbn Kutluboğa'nın Nüzhetü'n-Nazar Hâşiyesinde İbn Hacer'e Yönelttiği Tenkidler, 29-31; Aysan, 
19 | İsmâil Hakkı Bursevînnin Ali el-Kârîye Karşı Takındığı Olumsuz Tavrın Muhtemel Sebepleri

özellikle belirtmek isteriz. Aksi takdirde ilim talebeleri için, özellikle de içerdiği bol miktardaki Farsça ve Türkçe kelime izahlarından dolayı Farsça ve Türkçe bilen talebeler için çok faydalı olabileceğini düşündüğümüz bu şerhe haksızlık etmiş oluruz.

Mehmed et-Trabzonînnin er-Risâle fî Fenni Usûli'l-Hadîs: Hâş̧iye alâ Nüzheti'n-Nazar fî Tavdîhi Nuhbeti'l-Fiker Adlı Eseri ve Hadis Usûlüne Katkısı, 32-34, 35-36. 


\section{Kaynakça}

Akçay, Mustafa. "Ebeveyn-i Resul Tartışmalarında Zahidu'l-Kevserî’nin Yeri ve Bir Hatanın Düzeltilmesi”. Uluslararası Düzceli M. Zâhid Kevserî Sempozyumu 24-25 Kasım 2007 (Düzce 2007), 591-602.

Akçay, Mustafa. Ebeveyn-i Resûl Risâleleri. İstanbul: Yeni Akademi Yayınları, 2005.

Akçay, Mustafa. "Hz. Peygamber'in Anne-Babasının (Ebeveyn-i Resûl) Dînî Konumuna Dâir Ebû Hanîfe'ye Atfedilen Görüș Etrafındaki Tartışmalar". Sakarya Üniversitesi İlahiyat Fakültesi Dergisi 19 (Sakarya 2009), 1-27.

Akçay, Mustafa. "Kemâl Paşazâde ve "fî Hakkı Ebeveyni'n-Nebî" Adlı Risâlesinin Tahlil ve Değerlendirmesi". EKEV Akademi Dergisi -Sosyal Bilimler- 9/22 (Erzurum 2005), 127-142.

Akçe, Zübeyir. İsmâil Hakkı Bursevînnin Tuhfe-i Recebiyye Edlı Eseri (İnceleme-Metin). Urfa: Harran Üniversitesi Sosyal Bilimler Enstitüsü, Doktora Tezi, 2008.

Âkifzâde, Abdürrahîm b. İsmâil el-Amâsî el-Merzifonî. Kitâbü'l-Mecmû'fi'l-meșhûd ve'l-mesmû'. Milli Eğitim Bakanlığı Çorum İl Halk Ktp., 27011, 165 vr. (229 sayfa). çev. Hikmet Özdemir. İstanbul: Özfa Matbaacılık, 1998.

Akman, Mustafa. "Firavun'un İmânı Konusunda Celâleddin ed-Devvânî ile Ali el-Kârî Arasındaki Polemik". II. Uluslararası El Ruha Sosyal Bilimler Kongresi Tam Metin Kitabl, 9-11 Subat 2018 Șanlıurfa (Şanlıurfa 2018),15-20.

Akpınar, Ali. “Şemseddin Sivasî̀ye Göre Hz. Hızır’ın Kimliği / Mahiyeti”. Osmanlılar Döneminde Sivas: Sempozyum Bildirileri, 21-25 Mayıs 20072 (2007), 121-136.

Ali el-Kârî, Ali b. Sultân Muhammed el-Kârî. el-Edeb fî Receb. nşr. Meşhûr Hasen Selmân. Beyrut: el-Mektebü'l-İslâmî, 1411/1991.

Ali el-Kârî, Ali b. Sultân Muhammed el-Kârî. Edilletü mu'tekadi Ebî Hanîfete'l-A'zam fî (hakkı) ebeveyi'r-Rasûl aleyhi's-salâtü ve's-selâm. Süleymaniye Ktp., Damad İbrahim Paşa, 298. nşr. Meșhûr Hasen Selmân. Medine: Mektebetü'l-Gurabâi'l-Eseriyye, 1413/1993.

Ali el-Kârî, Ali b. Sultân Muhammed el-Kârî. el-Esrâru'l-merfûa fi'l-ahbâri'l-mevzûa (elMevzûâtü'l-kübrâ). nşr. Muhammed b. Lütfî es-Sabbâğ. Beyrut: el-Mektebü'l-İslâmî, 1406/1986.

Ali el-Kârî, Ali b. Sultân Muhammed el-Kârî. Ferrü'l-avn mimmen yeddaî (min müddeaî) îmâne (îmâni) Fir'avn. Süleymaniye Ktp., Esad Efendi, 1186, vr. 7-35. Mecmûatü resâil fî vahdeti'l-vücûd adlı mecmûanın içinde, İstanbul 1294, 115-163.

Ali el-Kârî, Ali b. Sultân Muhammed el-Kârî. Keş̧ü'l-hidr an emri'l-Hıdr. Süleymaniye Ktp., Fatih, 5327; Esad Efendi, 1446; Ârif Hikmet, 82/24, 211/9. el-Hazer fi emri'l-Hadır. nşr. Muhammed Hayr Ramazan Yûsuf. Dımaşk: Dârü'l-Kalem - Beyrut: Dârü'ş-Şâmiyye, $1411 / 1991$.

Ali el-Kârî, Ali b. Sultân Muhammed el-Kârî. Manzûme fí medhi't-Tarîkati'l-Muhammediyye li'lBirgivî. Süleymaniye Ktp., Dügümlü Baba, 150/1, vr. 1-2.

Ali el-Kârî, Ali b. Sultân Muhammed el-Kârî. Minahu'r-ravzi'l-ezher fî șerhi'l-Fikhi'l-ekber (Șerhu Kitâbi'l-Flkhi'l-ekber). nşr. Vehbî Süleymân Gâvcî (Nâşirin et-Ta'lîku'l-müyesser alâ şerhi'l-Fıkhi'l-ekber'i ile birlikte). Beyrut: Dârü'l-Beşâiri'l-İslâmiyye, 1419/1998.

Ali el-Kârî, Ali b. Sultân Muhammed el-Kârî. el-Minehu'l-fikriyye bi şerhi'l-Mukaddimeti'lCezeriyye [Kenarında Zekeriyyâ el-Ensârî'nin ed-Dekâiku'l-muhkeme fí şerhi'lMukaddimeti'l-Cezeriyye adlı eseriyle]. Kâhire 1302).

Ali el-Kârî, Ali b. Sultân Muhammed el-Kârî. Mirkâtü'l-mefâtîh şerhu Mişkâti'l-Mesâbîh. nşr. Cemâl Aytânî. 11 Cilt. Beyrut: Dârü'l-Kütübi'l-İlmiyye, 1422/2001.

Ali el-Kârî, Ali b. Sultân Muhammed el-Kârî. el-Mukaddimetü's-sâlime fí havfi'l-hâtime. nşr. Meşhûr Hasen Selmân. Beyrut: el-Mektebü'l-İslâmî - Ammân: Dâru Ammâr, $1409 / 1989$. 
Ali el-Kârî, Ali b. Sultân Muhammed el-Kârî. er-Red ale'l-kâilîn bi vahdeti'l-vücûd. nşr. Ali Rıza b. Abdullah b. Ali Rıza. Beyrut: Dârü'l-Me'mûn li't-Türâs, 1415/1995. Vahdet-i Vücud. çev. Harun Ünal, İstanbul: Gümüş Ofset, 1995. Risâle fì vahdeti'l-vücûd (Mecmûatü resâil fî vahdeti'l-vücûd adlı mecmûanın içinde). İstanbul 1294, 52-114.

Ali el-Kârî, Ali b. Sultân Muhammed el-Kârî. Risâle fì tefâvuti'l-mevcûdât. Berlin Ktp., 1639, 3369.

Ali el-Kârî, Ali b. Sultân Muhammed el-Kârî. Şemmü'l-avârız fí zemmi'r-Revâfiz. nşr. Meşhûr Hasen Selmân. Ammân: ed-Dârü'l-Eseriyye, 2008.

Ali el-Kârî, Ali b. Sultân Muhammed el-Kârî. Şerhu Şerhi Nuhbeti'l-fiker. nşr. Muhammed Nizâr Temîm - Heysem Nizâr Temîm (Abdülfettâh Ebû Gudde'nin takdimiyle). Beyrut: Dâru'l-Erkam b. Ebi'l-Erkam, ts.

Ali el-Kârî, Ali b. Sultân Muhammed el-Kârî. Şerhu'ş-Şifâ fî hukûki'l-Mustafâ. 2 Cilt. Beyrut: Dârü'l-Kütübi'l-İlmiyye, 1421/2000.

Ali el-Kârî, Ali b. Sultân Muhammed el-Kârî. et-Tecrîd fi i'râbi kelimeti't-tevhîd ve mâ yeteallaku bi ma'nâhâ mine't-temcîd. nşr. Meșhûr Hasen Selmân. Beyrut: el-Mektebü'l-İslâmî Ammân: Dâru Ammâr, 1411/1991.

Altuntaş, Mustafa Celil. Osmanlı Döneminde Hadis İlmi. İstanbul: İstanbul Üniversitesi Sosyal Bilimler Enstitüsü, Doktora Tezi, 2018.

Anay, Harun. "Devvânî". Türkiye Diyanet Vakfi İslâm Ansiklopedisi. 9/257-262. İstanbul: TDV Yayınları, 1994.

Arslan, Ahmet Turan. Imam Birgivî Hayatı Eserleri ve Arapça Tedrisatındaki Yeri. İstanbul: Seha Neşriyat, 1992.

Avcı, Seyit. Sûfilerin Hadis Anlayışı Bursevî Örneği. Konya: Ensar Yayıncılık, 2004.

Aydın, Süleyman. "Kur'ân ve Sünnet Ișığında Firavun'un İmânı Meselesi". Hitit Üniversitesi Ilahiyat Fakültesi Dergisi 13/26 (Çorum 2014/2), 121-148.

Aydınl, Abdullah. Doğuş Devrinde Tasavvuf ve Hadis. İstanbul: Seha Neşriyat, 1986.

Aydınlı, Abdullah. Hadis Istılahları Sözlügü. İstanbul: M.Ü. İlahiyat Fakültesi Vakfı Yayınları, 2011.

Aysan, Mehmet Ali. Mehmed et-Trabzonî'nin er-Risâle fî Fenni Usûli'l-Hadîs: Hâş̧iye alâ Nüzheti'n-Nazar fi Tavdîhi Nuhbeti'l-Fiker Adlı Eseri ve Hadis Usûlüne Katkısı. Bayburt: Bayburt Üniversitesi Sosyal Bilimler Enstitüsü, Yüksek Lisans Tezi, 2019.

Bardakçı, M. Necmettin. “İsmail Hakkı Bursevînnin Musa-Hızır Kıssası Yorumunun İlim-Marifet Uygunluğu Açısından Değerlendirmesi”. Süleyman Demirel Üniversitesi İlahiyat Fakültesi Dergisi 5 (Isparta 1998), 81-103.

Baz, İbrahim. Kadızadeliler Sivasiler Tartışması. Ankara: OTTO, 2019.

Beyazîzâde, Ahmed b. Hasen el-Bosnevî. el-Usûlü'l-münîfe li'l-Imâmi Ebî Hanîfe. nşr. İlyas Çelebi, İstanbul: M.Ü. İlahiyat Fakültesi Vakfı Yayınları, 1416/1996. İmam Azam Ebu Hanife'nin İtikadî Görüşleri. çev. İlyas Çelebi. İstanbul: M.Ü. İlahiyat Fakültesi Vakfı Yayınları, 1996.

Bilkan, Ali Fuat. Fakihler ve Sofuların Kavgası 17. Yüzyılda Kadızâdeliler ve Sivâsîler. İstanbul: İletişim Yayınları, 2019.

Bilmen, Ömer Nasuhi. Büyük Tefsir Tarihi Tabakatü'l-Müfessirîn. 2 Cilt. İstanbul: Diyanet İşleri Reisliği Yayınları, 1960.

Bursevî, İsmâil Hakkî. Ferâhu'r-rûh (SSerhu'l-Muhammediyye). İstanbul 1294.

Bursevî, İsmâîl Hakkî. Furûku Hakkî. [Mehmet Faruk Çifçi. İsmâil Hakkı Bursevî́nin Furûk-ı Hakkı Adlı Eseri (İnceleme ve Tahkik). İstanbul: Marmara Üniversitesi Sosyal Bilimler Enstitüsü, Doktora Tezi, 2013].

Bursevî, İsmâîl Hakkî. Kırk Hadis Şerhi. nşr. Sami Erdem. arş. Hikmet Gültekin. İstanbul: İnsan Yayınları, 2005. Şerhu'l-Erbaîne hadîsen. İstanbul: Dâru't-Tıbâati'l-Âmire, 1317/1899. 
Bursevî, İsmâîl Hakkî. Kitâbü'l-Hitâb. İstanbul 1256. Manevî Ufuklar II Kitâbu'l-Hitâb. sadeleștiren İ. Turgut Ulusoy. İstanbul: Hisar Yayınları, 1983.

Bursevî, İsmâîl Hakkî. Kitâbü'n-Necât. Konya Yazma Eserler, 1789. İstanbul 1290. Manevî Ufuklar I Kitâbu'n-Necât. sadeleștiren İ. Turgut Ulusoy, İstanbul: Hisar Yayınları, 1983.

Bursevî, İsmâîl Hakkî. Kitâbü'n-Netîce. nşr. Ali Namlı-İmdat Yavaş. 2 Cilt. İstanbul: İnsan Yayınları, 1997.

Bursevî, İsmâîl Hakkî. Kitâbu's-Silsileti'l-Celvetiyye (Silsile-i Celvetiyye, Silsilenâme-i Celvetî). Millet Ktp., Şer'iye, 1040. İlyas Efendi. İsmail Hakkı Bursevi'nin Kitâbu's-Silsileti'lCelvetiyye'si. İstanbul: Marmara Üniversitesi Sosyal Bilimler Enstitüsü, Yüksek Lisans Tezi, 1994.

Bursevî, İsmâîl Hakkî. Min vâridâti'l-Fakîr eș-Şeyh İsmâîl Hakkî min evâhiri Zilhicce min seneti 1116. Süleymâniye Ktp., Hâlet Efendi, 789, vr. 56b-222a.

Bursevî, İsmâîl Hakkî. Risâletü İbn Hacer fî ilmi'l-hadîs. İnebey (BEYBEK), Genel, 34.

Bursevî, İsmâîl Hakkî. Rûhu'l-beyân fî tefsîri'l-Kur'ân. nşr. Abdüllatîf Hasen Abdurrahmân. 10 Cilt. Beyrut: Dârü'l-Kütübi'l-İlmiyye, 1430/2009. Rûhu'l-Beyân Kur'an Meâli ve Tefsiri. çev. Heyet. 23 Cilt. İstanbul: Erkam Yayınları, 2011-2016.

Bursevî, İsmâîl Hakkî. Rûhu'l-Mesnevî (Şerhu'l-Mesnevî). bk. İsmail Güleç. Mesnevî Şerhi Rûhü'lMesnevî -Mesnevî́nin İlk 748 Beytinin Şerhi- İsmail Hakkî Bursevî. İstanbul: İnsan Yayınları, 2012.

Bursevî, İsmâîl Hakkî. Şerh-i Pend-i Attâr. İstanbul 1287. Tuba Onat Çakıroğlu. İsmail Hakkı Bursevî́nin "Şerh-i Pend-i Attâr" (Attâr'ın Pendnâmesi'nin Açılaması) Adlı Eseri Üzerine Bir İnceleme ve Attâr'ın Pendnâme'si İle Karșılaștırılması. Ankara: Hacettepe Üniversitesi Sosyal Bilimler Enstitüsü, Doktora Tezi, 2012).

Bursevî, İsmâîl Hakkî. Şerhu'l-Erbaîne hadîsen. İstanbul: Dâru't-Tıbâati'l-Âmire, 1317/1899. Kırk Hadis Şerhi. nşr. Sami Erdem. arş. Hikmet Gültekin. İstanbul: İnsan Yayınları, 2005).

Bursevî, İsmâîl Hakkî. Şerhu Nuhbeti'l-fiker. İnebey (BEYBEK), Genel, 35-37. Kasîdecizâde, Süleymâniye Ktp., 46. [Necmi Sarı. İsmail Hakkı Bursevî́nin Şerhu Nuhbeti'l-Fiker Adlı Eserinin Tahkik ve Tahlili. Sakarya: Sakarya Üniversitesi Sosyal Bilimler Enstitüsü, Doktora Tezi, 2017].

Bursevî, İsmâil Hakkî. Tamâmü'l-feyz fî bâbi'r-ricâl. [Ramazan Muslu ve Ali Namlı. İsmâil Hakkı Bursevî ve Tamâmü'l-Feyz Adlı Eseri-I ve II. İstanbul: Marmara Üniversitesi Sosyal Bilimler Enstitüsü, Yüksek Lisans Tezi, 1994].

Bursevî, İsmâîl Hakkî. Tuhfe-i Recebiyye. bk. Zübeyir Akçe. İsmâil Hakkı Bursevî́nin Tuhfe-i Recebiyye Edlı Eseri (İnceleme-Metin). Urfa: Harran Üniversitesi Sosyal Bilimler Enstitüsü, Yayımlanmamıș Doktora Tezi, 2008.

Bursevî, İsmâil Hakkî. el-Vâridât. İnebey (BEYBEK), Genel, 67.

Cengiz, Osman. 16. Yüzyıl Osmanlı Düşüncesinin Kaynakları Çivizâde - Ebusu'ûd - Birgivî. İstanbul: Ketebe Yayınları, 2018.

Çakıroğlu, Tuba Onat. İsmail Hakkı Bursevî̀nin "Şerh-i Pend-i Attâr" (Attâr'ın Pendnâmesi'nin Açıklaması) Adlı Eseri Üzerine Bir İnceleme ve Attâr'ın Pendnâme'si İle Karșıllaștırılması. Ankara: Hacettepe Üniversitesi Sosyal Bilimler Enstitüsü, Doktora Tezi, 2012.

Çavuşoğlu, Semiramis. "Kadızâdeliler”. Türkiye Diyanet Vakfi İslâm Ansiklopedisi. 24/100-102. İstanbul: TDV Yayınları, 2001.

Çınar, Mahmut. "Ye's ve Be’s Halinde İmânın Hükmü: Firâvun'un İmânı Örneği”. M.Ü. İlâhiyat Fakültesi Dergisi [İstanbul Yüksek İslam Enstitüsü Dergisi] [MÜIFD] 41 (İstanbul 2011/2), 121-142.

Çiçek, Yakup. "İsmâil Hakkı Bursevî”. Îman Esaslarına Tasavvufi Bir Bakış (Şerh-u Şu'abi'lÎmân). İstanbul: Dârulhadis, 2000, 17-38. 
Değaş b. Şebîb el-Acmî. İbn Arabî akîdetuhu ve mevkıfu ulemâi'l-müslimîn minhu mine'l-karni'ssâdis ile'l-karni's-sâlis aşer. Kuveyt: Mektebetü Ehli'l-Eser, 1432/2011.

Demir, Abdullah. "Osmanlı Âlimlerinin Ebû Hanîfe'nin Akâid Risâlelerini Konu Edinen Eserleri $=$ The Works of Ottoman Scholars on Abu Hanifa's Article of Faith". Türkiye Araştırmaları Literatür Dergisi Türkiye'de İslami İlimler: Kelâm ve Mezhepler Tarihi II 14/28 (İstanbul 2016), 169-226.

Devvânî, Celâlüddîn Muhammed ed-Devvânî. Risâle fî îmâni Fir'avn. Süleymaniye Ktp., Pertevniyal, 929.

Ebü'l-Müntehâ, Ahmed b. Muhammed el-Mağnisâvî. Şerhu'l-Flkhi'l-ekber. İstanbul 1278.

Elmalı, Hüseyin. "Birgivî Hakkında Mısır, Mekke ve Medine Âlimlerinin Söylediği Bazı Şiirler”. İmam Birgivî. Ed. Mehmet Şeker. 83-101. Ankara: Türkiye Diyanet Vakfi, 1994.

Engin, Sezai. “Hadis Litaratüründe Hâşiyeler: Nuhbetü'l-fiker ve Nüzhetü'n-nazar Üzerine Yapılan Hâşiye Çalışmaları Bibliyografyası". Hadis ve Siyer Araştırmaları 1/1 (İstanbul 2015), 77-98.

Erul, Bünyamin. "Uydurma Rivayetlerde Peygamber Tasavvuru". İslâm'ın Anlaşılmasında Sünnetin Yeri ve Değeri, Kutlu Doğum Sempozyumu 2001 (Ankara: Türkiye Diyanet Vakfı Yayınları, 2003), 419-438.

Güleç, İsmail. İsmâil Hakkı Bursevî́nin 'Rûhu'l-Mesnevî'sinin İncelenmesi. İstanbul: İstanbul Üniversitesi Sosyal Bilimler Enstitüsü, Doktora Tezi, 2002.

Güleç, İsmail. Mesnevî Şerhi Rûhü'l-Mesnevî -Mesnevî̀nin İlk 748 Beytinin Şerhi- İsmail Hakkî Bursevî. İstanbul: İnsan Yayınları, 2012.

Güller, Muhammed Emin. İbn Kutluboğa'nın Nüzhetü'n-Nazar Hâşiyesinde Ibn Hacer'e Yönelttiği Tenkidler. Tokat: Tokat Gazi Osmanpaşa Üniversitesi Sosyal Bilimler Enstitüsü, Yüksek Lisans Tezi, 2018.

Gündoğdu, Cengiz. "Sivâsî, Abdülmecid". Türkiye Diyanet Vakfı İslâm Ansiklopedisi. 37/286287. İstanbul: TDV Yayınları, 2009.

Gündoğdu, Cengiz. "XVII. Yüzyılda Tekke-Medrese Münâsebetleri Açısından Sivâsîler - Kadızâdeliler Mücâdelesi". ILAM Araştırma Dergisi 3/1 (Ocak-Haziran 1998), 37-72.

Gölcük, Şerafettin - Bebek, Adil. "el-Fıkhü'l-ekber". Türkiye Diyanet Vakfı İslâm Ansiklopedisi. 12/544-547. İstanbul: TDV Yayınları, 1995.

Gömbeyaz, Kadir. “Vânî Mehmed Efendi'nin Hz. İbrahim'in Babası ve Ebeveyn-i Resûl Hakkındaki Görüssleri". Ulusal Vânî Mehmed Efendi Sempozyumu 7-8 Kasım 2009, Kestel-Bursa-Bildiriler- (Bursa 2011), 205-232.

Harman, Ömer Faruk. "Firavun". Türkiye Diyanet Vakfı İslâm Ansiklopedisi. 13/118-121. İstanbul: TDV Yayınları, 1996.

Has, Şükrü Selim. "Halebî İbrâhim b. Muhammed". Türkiye Diyanet Vakfi İslâm Ansiklopedisi. 15/231-232. İstanbul: TDV Yayınları, 1997.

İbn Âbidîn, Muhammed Emîn ed-Dımaşkî. Tenbîhu'l-vülât ve'l-hukkâm alâ ahkâmi şâtimi hayri'l-enâm ev ahadi's-sahâbeti'l-kiram (Mecmûatü resâil İbn Âbidîn içinde, 1/313371). 2 Cilt. İstanbul: Dersaâdet, 1325/1907.

İbn Hacer, Ahmed b. Alî el-'Askalânî. ez-Zehrü'n-nadr fî nebe'i (hâli)'l-Hadr. nşr. Salâhuddîn Makbûl Ahmed. Kuveyt: Mektebetü Ehli'l-Eser, 1425/2004. Rivâyet İlimleri Açısından Hızırın Nübüvvet ve Hayat Meselesi. çev. M. Beşir Eryarsoy. İstanbul: Ümmülkura Yayınları, 2006.

İbn Teymiyye, Ahmed b. Abdülhalîm el-Harrânî. Mecmû'u'l-fetâvâ. cem ve tertîb: Abdurrahmân b. Muhammed b. Kâsım en-Necdî. 37 Cilt. Riyâd: Dâru Âlemi'l-Kütüb, $1412 / 1991$.

İbn Teymiyye, Ahmed b. Abdülhalîm el-Harrânî. Risâle fi'r-reddi alâ İbn Arabî fî da'vâ îmâni Fir'avn (Câmiu'r-resâil içinde). nşr. Muhammed Reşâd Sâlim. 2 Cilt. Cidde: Dârü'lMedenî, 1405/1984. 
İbn Kayyim el-Cevziyye, Muhammed b. Ebî Bekr ez-Züra'î ed-Dımaşkî. el-Menâru'l-münîf fi'ssahîhi ve'd-da'îf. nşr. Abdurrahmân b. Yahyâ el-Mu'allimî-Mansûr b. Abdülazîz esSimârî. Riyâd: Dâru'l-Âsıme, 1416/1996.

İbn Kemâl (Kemalpaşazâde), Şemseddin Ahmed. Risâle fî hakkı ebeveyi'n-Nebî (Resâil-i İbn Kemal Paşa içinde yedinci risâle, 77-91). nşr. Ahmed Cevdet. İstanbul: İkdâm Matbaası, 1316/1898.

İbrâhim el-Halebî, İbrâhim b. Muhammed el-Halebî. Ni'metü'z-zerî'a fî nusrati'ş-şerî'a. nşr. Alî Rızâ b. Abdullah b. Alî Rizâ. Riyâd: Dâru'l-Mesîr, 1419/1998.

İbrâhim el-Halebî, İbrâhim b. Muhammed el-Halebî. Tesfỉhü'l-gabî fî tenzîhi İbn Arabî. nşr. Ebü'l-Berâ' Alî Rizâ b. Abdullah b. Alî Rızâ el-Medenî. Kâhire: Dârü'l-Meâric, $1429 / 2008$.

İpşirli, Mehmet. "Çivizâde Muhyiddin Mehmed Efendi". Türkiye Diyanet Vakfı İslâm Ansiklopedisi. 8/348-349. İstanbul: TDV Yayınları, 1993.

Martı, Huriye. Birgivî Mehmet Efendi. Ankara: Türkiye Diyanet Vakfı Yayınları, 2011.

Martı, Huriye. Osmanlı'da Bir Dâru'l-Hadîs Şeyhi Birgivî Mehmed Efendi. İstanbul: Dârulhadis, 2008.

Mehmed Ali Aynî (1869-1945). İsmail Hakkı Bursalı ve Rûhu'l-Beyan Müellifi. nşr. İsmail Dervişoğlu. İstanbul: Büyüyen Ay, 2013.

Miras, Kâmil. Sahîh-i Buhârî Muhtasarı Tecrîd-i Sarîh Tercemesi ve Şerhi. 13 (15) Cilt. Ankara: Diyânet İşleri Başkanlığı Yayınları, 1985.

Naîmâ, Mustafa. Târîh-i Naîmâ (Ravzatü'l-hüseyn fî hulâsati ahbâri'l-hâfikayn). 6 Cilt. İstanbul: Matbaa-i Âmire, 1280.

Namlı, Ali. İsmâil Hakkı Bursevî Hayatı, Eserleri, Târikat Anlayışı. İstanbul: İnsan Yayınları, 2001.

Namlı, Ali. "İsmâil Hakkı Bursevî Hazretlerinin Hayatı ve Eserleri”. Rûhu'l-Beyân Kur'an Meâli ve Tefsiri. 1/9-38. İstanbul: Erkam Yayınları, 1432/2011.

Naml, Ali. "İsmâil Hakkı Bursevî'nin Rûhu'l-Beyân fî Tefsîri'l-Kur'ân Adlı Tefsîri”. Türkiye Araștırmaları Literatür Dergisi 9/18 (İstanbul 2011), 365-385.

Naml, Ali. 'XVIII. Yüzyılda İbnü'l-Arâbî’yi Tartışmak: İsmâil Hakkı Bursevî̀nin Firavun'un İmanı Meselesine Yaklaşımı". Osmanlı'da İlm-i Tasavvuf. 475-490. İstanbul: İsar Yayınları, 2018.

Kalaycı, Mehmet. "Birgivî Mirasının Toplumsal ve Metinsel Taşıyıcıları: Kadızâdeliler ve Etrafındaki Ulema". Sahn-ı Semân'dan Dârulfünûn'a Osmanlı'da İlim ve Fikir Dünyası (Âlimler, Müesseseler ve Fikrî Eserler) - XVII. Yüzyıl Sempozyum Tebliğleri. ed. Hidayet Ardar - Ali Fikri Yavuz. 431-455. İstanbul: Zeytinburnu Belediyesi, 2017.

Kalaycı, Mehmet. Osmanlı Sünniliği Tarihsel-Sosyolojik Bir Tahlil Denemesi. Ankara: Otorite Yayınları, 2015.

Karadaş, Cağfer. "Alî el-Kârî’nin Hayatı, Selef Akîdesine Dönüş Çabası ve Eserleri”. Uludağ Üniversitesi İlahiyat Fakültesi Dergisi 5/5 (Bursa 1993), 287-299.

Karadaş, Cağfer. İbn Arabî’nin İtikadî Görüșleri. İstanbul: Beyan Yayınları, 1997.

Karadaş, Cağfer. "İsmail Hakki Bursevî’nin İtikadî Görüşleri”. Uludağ Üniversitesi İlahiyat Fakültesi Dergisi 8/8 (Bursa 1999), 265-276.

Karadaş, Cağfer. "Muhyiddin İbn Arabî'nin İtikâdı", Tasavvuf: İlmî ve Akademik Araştırma Dergisi (İbnü'l-Arabî Özel Sayısı-1) 9/21 (2007), 67-94.

Karadaş, Cağfer. "Sivâsîler-Kadızâdeliler Olayı ve İnanç Boyutu", İlim ve Kültür Tarihinde Sivâsîler Ulusal Sempozyumu Tebliğleri 30 Nisan-1Mayıs 2010 Sivas, TSO Konferans Salonu (2011), 107-124.

Karagöz, Mehmet. “Osmanlı Fikir Hayatında Kadızâdeliler Hareketi”, Türkler 11 (Ankara: Yeni Türkiye Yayınları, 2002), 65-148. 
25 | İsmâil Hakkı Bursevî’nin Ali el-Kârî’ye Karşı Takındığı Olumsuz Tavrın Muhtemel Sebepleri

Kara, İsmail. İlim Bilmez Tarih Hatırlamaz Şerh ve Haşiye Meselesine Dair Birkaç Not. İstanbul: Dergâh Yayınları, 2014.

Kara, İsmail. "Unuttuklarını Hatırla! Şerh ve Haşiye Meselesine Dair Birkaç Not". Dîvân Disiplinlerarası Çalışmalar Dergisi 15/28 (İstanbul 2010/1), 1-67.

Kara, Mustafa. Tasavvuf ve Tarikatlar Tarihi. İstanbul: Dergâh Yayınları, 1985.

Kâtib Çelebi, Hacı Halîfe Mustafa b. Abdullah. Fezleke-i Kâtib Çelebi. 2 Cilt. İstanbul: Cerîde-i Havâdis Matbaası, 1310.

Kâtib Çelebi, Hacı Halîfe Mustafa b. Abdullah. Mîzânu'l-hak fî ihtiyâri'l-ehak İslâmda Tenkid ve Tartışma Usûlü. haz. Mustafa Kara. İstanbul: Marifet Yayınları, 1981.

Kesgin, Salih. Hadisleri Anlama Sorunu. İstanbul: İSAM Yayınları, 2019.

Kevserî, Muhammed Zâhid el-Kevserî. “Ebû Hanîfe'nin el-Âlim ve'l-müteallim adlı eserine yazdığı mukaddime". Kâhire 1368/1949.

Koca, Ferhat. "Osmanlılar Dönemi Fıkıh Tasavvuf İlişkisi: Fakılar İle Sofular Mücadelesinin Tarihi Serüveni". Gazi Üniversitesi Çorum İlahiyat Fakültesi Dergisi 1/1 (Çorum 2002/1), 73-131.

Kutlay, Halil İbrahim. el-İmâm Alî el-Kârî ve Eseruhu fí İlmi'l-Hadîs. Beyrut: Dârü'l-Beşâiri'lİslâmiyye, 1408/1987.

Leknevî, Abdülhay el-Leknevî. et-Ta'lîkâtü's-seniyye ale'l-Fevâidi'l-behiyye (el-Fevâidü'lbehiyye fi terâcimi'l-Hanefiyye ile birlikte). nşr. Muhammed Bedreddîn Ebû Firâs enNa'sânî. Kâhire: Matbaatü's-Saâde, 1324/1906.

Özben, Zübeyde. "Hanefiller'in Mukaddime Temelli Hadis Usulü Literatürüne Katkısı". İslâm Araştırmaları Dergisi 36 (İstanbul 2016), 1-31.

Özel, Ahmet. "Ali el-Kârî". Türkiye Diyanet Vakfi İslâm Ansiklopedisi. 2/403-405. İstanbul: TDV Yayınları, 1989.

Özervarl, M. Sait. İbn Teymiyye'nin Düşünce Metodolojisi ve Kelâmcllara Eleștirisi. İstanbul: İSAM Yayınları, 2008.

Sarı, Necmi. "Birgivî̀yi Öven Manzûmelerin Kritiği". Ballkesirli Bir İslam Âlimi İmam Birgivî. Ed. Mehmet Bayyiğit - Mehmet Özkan - Ahmet Ali Çanakcı - Asem Hamdy Abdelghany. 3 Cilt. 3: 578-618. Balıkesir: Balıkesir Büyükşehir Belediyesi Kültür Yayınları, 2019.

Sarı, Necmi. Hadislerde Teșebbüh Yasağı. İstanbul: Marmara Üniversitesi Sosyal Bilimler Enstitüsü, Yüksek Lisans Tezi, 2010.

Sarı, Necmi. İsmail Hakkı Bursevî́nin Şerhu Nuhbeti'l-Fiker Adlı Eserinin Tahkik ve Tahlili. Sakarya: Sakarya Üniversitesi Sosyal Bilimler Enstitüsü, Doktora Tezi, 2017.

Sarı, Necmi. "Kendi Dilinden İsmâil Hakkî Bursevînin Hayatı ve Şahsiyeti”. KTÜ İlahiyat Fakültesi Dergisi 2/3 (Trabzon 2015), 137-157.

Soyal, Fikret. Celâleddin ed-Devvânî́nin Firavun'un İmânı Konusundaki Görüşleri ve Ali elKârî́nin Eleștirisi. İstanbul: İstanbul Üniversitesi Sosyal Bilimler Enstitüsü, Yüksek Lisans Tezi, 2004.

Süyûtî, Celâluddîn es-Süyûtî. er-Resâilü't-tis'u. Haydarâbâd: Matbaatü Dâireti'l-Meârifi'lOsmâniyye, 1380/1961.

Şeyhî Mehmed Efendi. Vakâyiu'l-fudalâ', Şekâiku Nu'mâniyye ve Zeyilleri. nşr. Abdülkadir Özcan. 5 Cilt. İstanbul: Çağrı Yayınları, 1989.

Tonga, Aydın. Osmanlı'nın Paralel Devleti Kadızadeliler. İstanbul: Doğu Kitabevi, 2017.

Topuzoğlu, Tevfik Rüştü. "Hâş̧iye". Türkiye Diyanet Vakfi İslâm Ansiklopedisi. 16/419-422. İstanbul: TDV Yayınları, 1997.

Uysal, Muhittin. "Tespit ve Yorum Bakımından Hızır'la İlgili Haberler”. Selçuk Üniversitesi İlahiyat Fakültesi Dergisi 10 (Konya 2000), 337-366.

Uzunçarşıll, İsmail Hakkı (1888-1977). Osmanlı Tarihi. 3 ve 4. Ciltler. Ankara: Türk Tarih Kurumu, 1988. 
Vehbî Süleymân Gâvcî. et-Ta'lîku'l-müyesser alâ şerhi'l-Fıkhi'l-ekber. Beyrut: Dârü'l-Beşâiri'lİslâmiyye, 1419/1998.

Yavuz, Yusuf Şevki -Karadaș, Cağfer. "İsmâil Hakkı Bursevî İtikâdî Görüşleri”. Türkiye Diyanet Vakfi İslâm Ansiklopedisi. 23/108-110. İstanbul: TDV Yayınları, 2001.

Yıldız, Sâkıb. "Türk Müfessiri İsmail Hakkı Burûsevi'nin Hayatı". Atatürk Üniversitesi İslâmî İlimler Fakültesi Dergisi 1 (Erzurum 1975), 103-126.

Yüksel, Emrullah. "Birgivî". Türkiye Diyanet Vakfı İslâm Ansiklopedisi. 6/191-194. İstanbul: TDV Yayınları, 1992. 